\title{
Public Creditors of Financial Institutions: The Case for a Derivative Right of Action*
}

Financial intermediaries ${ }^{1}$ play an important role in the economy by channeling funds from suppliers of capital to business corporations and other "ultimate investors." They obtain the bulk of this capital not from stockholders but from public creditors ${ }^{2}$-bank depositors, savings and loan association accountholders, ${ }^{3}$ and life insurance policyholders.

Despite the public creditor's position as capital supplier and often as legal owner of the enterprise, his present legal status leaves him effectively powerless to combat insider misconduct in ongoing institutions. Recent developments and research that indicate the existence of widespread managerial misconduct in financial institutions demonstrate the importance of the problem for the financial system as a whole.

This Note recommends a new statute to give public creditors the right to bring derivative actions on behalf of their institutions. Part I outlines the need for greater protection both of the public creditor and of the integrity of the financial system. Part II discusses the appropriateness of a derivative suit as a remedy. Part III proposes legislation to create a derivative right of action and considers objections the proposal is likely to encounter.

* The author thanks Professor Robert Charles Clark for his guidance and helpful comments on earlier drafts.

1. Financial intermediaries serve as middlemen between capital suppliers (such as savers, depositors, and policyholders) and investors in real assets. Clark, The Federal Income Taxation of Financial Intermediaries, 84 YALE L.J. 1603, 1605 (1975). This Note focuses upon commercial banks, life insurance companies, mutual savings banks, and savings and loan associations (S\&Ls). These institutions are "first order financial intermediaries," which obtain the bulk of their capital from individual households. Id. at 1606. Many of the arguments contained herein apply with equal force to other first order financial intermediaries that obtain the bulk of their funds from public creditors who have a financial interest in the earnings of the institution. These include mutual funds and private pension plans, see pp. $1449-52$ infra, real estate investment trusts, see Clark, supra at 1606, and credit unions. "Second order financial intermediaries" obtain capital directly from other financial institutions, primarily from first order financial intermediaries; they include the Federal Reserve Banks, Federal Home Loan Banks, and finance companies. Id. This Note does not discuss second order financial intermediaries.

2. "Public creditor," or "public supplier of capital," denotes the individual saver. Sec Clark, supra note 1, at 1617 (defining public suppliers of capital as "those belonging to a legally distinct class comprised of members who are numerous, of relatively modest means on the average, and who typically supply the greatest bulk of capital to the particular kind of financial institution"). Public creditors supply all the capital in mutual financial institutions and almost all the capital in stock institutions. See note 20 infra.

3. "Accountholder" is used in this Note to denote the "depositor" or "sharcholder" in an S\&L. 


\section{The Need for Greater Protection}

\section{A. Insider Misconduct in Financial Institutions}

\section{Misconduct by officers and directors of financial institutions typ-} ically stems from conflicts of interest and takes the form of selfdealing. The most common and intractable instances of such misconduct involve loans to insiders and insider transactions in property or services on terms unfavorable to the institution. ${ }^{4}$ Conflicts of interest are widespread. 5 Officers and directors often have financial interests in other enterprises that can offer services to the institution or that are in need of financing. ${ }^{6}$ Financing, ranging from business loans to home mortgages and real estate development, is a large part of the activity of financial institutions and requires a variety of

4. The misconduct that led to the demise of U.S. National Bank of San Diego and Franklin National Bank of Chicago took the form of self-serving transactions with companies affiliated with insiders. See note 8 infra. Commentators appear to be most concerned with the kinds of misconduct noted in the text, see notes 5 \& 6 infra, and rules of the major regulatory agencies reflect the same orientation. See pp. 1425, 1434-35, 1437, 1440 \& notes $12,51,65$ infra. The Comptroller of the Currency has stated to the Senate Subcommittee on Financial Institutions that most problem banks that he looks at involve some elements of this self-serving type of lending. Financial Structure and Regulation: Hearings Before the Subcomm. on Financial Institutions of the Senate Comm. on Banking, Housing and Urban Affairs, 93d Cong., lst Sess. 384 (1973) [hereinafter cited as Senale Hearings]. See Comm. \& Fin. Chron., May 20, 1974, at 11 (quoting FDIC board member's speech blaming insider loans for the failures of U.S. National Bank in San Diego, California, the Birmingham-Bloomfield bank, and Sharpstown State Bank of Houston, Texas, and the near-failure of the Bank of the Commonwealth in Detroit, Michigan).

5. See generally $J$. Brooks, Conflicts of Interest: Corporate Pension Fund Asset Management (1975); E. Herman, Conflicts of Interest: Commercial Bank Trust DepartMents (1975); N. Wolfson, Conflicts of INterest: InvestMent Banking (1976); Herman, Conflict of Interest in the Savings and Loan Industry, in II STUdY of THE SAviNcs AND LOAN INDUSTRY 763 (I. Friend ed. 1969); Hester, Opportunity and Responsibility in a Financial Institution, in I STAFF of House CoMm. ON BANking, CuRRENCY ANd Housing, 94th Cong., 2d Sess., Financial Instirutions and the Nation's Economy 173 (Comm. Print 1976) [committee print hereinafter cited as FINE STUdy Papers].

6. The directors of a financial institution usually include two or three officers, a representative of the institution's law firm, individuals affiliated with firms that work in ficlds closely related to the financial institution, individuals affiliated with other financial institutions, and other individuals who can contribute special skills. Hester, supra note 5, at 178. For an excellent study of such conflicts of interest in the S\&L area, see Herman, supra note 5 . The problem areas that Professor Herman isolates and analyzes include: strong links between officers and directors of S\&Ls and enterprises that conduct large amounts of business with the S\&LL, resulting in such problems as part-time dual management and joint occupancy of S\&L-owned office buildings (id. at 803-19); links between S\&L control groups and contractors and developers in connection with the extensive activities of S\&Ls in construction and land ownership and development (id. at 819-33); connections between S\&L officers, directors, and control groups and real estate brokers (id. at 833-47); director and officer interlocks with commercial banks and other financial institutions (id. at 870-85); and nepotism (id. at 885-92). New Federal Home Loan Bank Board (FHLBB) regulations will restrict certain of these conflict situations. See notes $12 \& 51$ infra. 
services, from appraisals and legal advice to real estate brokerage. When officers and directors, who control the institution's investment policy, can offer such services or have interests in related enterprises, the temptations to stand on both sides of a transaction are great. ${ }^{7}$

That the problem of insider misconduct in financial institutions is both current and significant is documented by recent failures of several prominent banks and insurance companies due primarily to selfdealing, ${ }^{8}$ as well as by government and academic investigations. ${ }^{\circ}$ The National Association of Insurance Commissioners reports that $77 \%$ of the 101 life insurance company insolvencies between 1963 and 1972 were caused primarily by management dishonesty. ${ }^{10}$ The Federal Deposit Insurance Corporation (FDIC) estimates that of ninety bank

7. See Hester, supra note 5 , at 178-79.

8. The Franklin National Bank of Chicago failed in 1974. The bank had been plagued by amateurish management, questionable loan practices, excessive salary expenses, and unfavorable lease agreements. The final straw was the disclosure that $\$ 4$ million in foreign exchange profits were bogus, a result of self-serving speculation by insiders. The presence of this self-serving speculation has been confirmed by the Sccurities and Exchange Commission (SEC) and forms the basis for a shareholder suit against the bank, its parent corporation, and twenty directors. See Rose, What Really Went Wrong at Franklin National, Fortune, Oct. 1974, at 118, 120, 220, 223, 225-26; Wall St. J., Aug. 12, 1974, at 12, col. 2; id., July 5, 1974, at 18, col. 1. See also pp. 1438-39 \& note 70 infra. The U.S. National Bank of San Diego became insolvent in 1973 as a result of illegal loans totaling $\$ 297.4$ million and an additional $\$ 91$ million in letters of credit, all issued to businesses controlled by the bank's president and major shareholder, C. Arnholdt Smith, or by his associates. The illegal loans represented over half of the bank's loan portfolio. See Bank of San Diego-No runs needed, Economist, Oct. 27, 1973, at 109; Wall St. J., Oct. 22, 1973 , at 5 , col. 1 ; id., Oct. 19, 1973, at 28, col. 1 .

For additional documentation of the causal role of official self-dealing in recent bank failures, see Barnett, Anatomy of a Bank Failure, BANking AD., Apr. 1972, at 21; Benston, Bank Examination, The Bullerin, May 1973, at 38-41 (New York Univ. Grad. School of Bus. Ad.); Dunne, Liability of Bank Directors Under the New Federal Common Law or Swift v. Tyson Resurgent, 8 Forum 286, 294 (1972); LeMaistre, Self-Dealing a Factor in Most Bank Failutes, Money MaNager, May 20, 1974, at 9; Morse, Bank Insiders and the Willful Misapplication Statute: Toward More Effective Protection from Self-Dealing, 92 Banking L.J. 715 (1975); Scott \& Mayer, Risk \& Regulation in Banking: Some Proposals for Federal Deposit Insurance Reform, 23 STAN. L. REv. 857, 861 (1971).

Exploitation of insurance subsidiaries by insurance holding company managements has caused a number of recent life insurance company failures. One example is the Equity Funding scandal of 1973, the "biggest corporate fraud" in U.S. business history. N.Y. Times, Apr. 2, 1975, at 58, col. 4. The officers of the Equity Funding Corporation of America, a large insurance holding company, used its subsidiary, Equity Funding Life Insurance Company, as the "cornerstone" in a scheme involving the fabrication of over 60,000 life insurance policies representing $\$ 2$ billion (which were sold to a reinsurer for cash), phony death claims, and $\$ 120$ million in phony assets. Id.; id., Nov. 2, 1973, at 1, col. 1. Another example is the Standard Life Corporation, a large holding company now insolvent because of "twice-pledged collateral, computer fraud, executive self-dealing, forgeries, cmbezzlement, and stock manipulation." Bus. WeEK, Feb. 3, 1975, at 48, 48.51. For an account of other life insurance company failures due to insider misconduct, sce H. Josephon, Life Insurance and the Public Isterest 76-83 (1971).

9. See note 5 supra.

10. National Ass'n of Ins. Comm'rs, Strengthening the Surveillance System: Final Report, at 3-1 to 3-3 (McKinsey \& Co., Apr. 1974). 
failures since 1960, fifty-one were due to self-dealing, twenty-five to defalcations, and only fourteen to "honest" bad management.11 In 1976, after widespread publicity about the role of insider misconduct in failed banks, administrative agencies finally promulgated regulations to govern certain insider transactions. ${ }^{12}$

\section{B. The Interests of the Public Creditor}

The public creditors of mutual financial institutions ${ }^{13}$ are the legal owners of the business. ${ }^{14}$ As such, they possess many of the proprietary

11. Ailing banks are hard to spot, Bus. WEEk, Nov. 8, 1976, at 108-09. For additional estimates, see Barnett, supra note 8 (18 of 54 recent bank failures were due to misuse of brokered funds and self-serving loans, 13 to self-serving loans alone, 13 to defalcations and embezzlement, 7 to bad loans and lax collection, and 3 to miscellaneous problems); Benston, supra note 8, at 40 (of 56 bank failures between Jan. 1959 and Apr. 197I, fraud and irregularities accounted for 37, losses from self-serving loans and/or excessively brokered funds for 15, and ineptness for only 4); LeMraistre, supra note 8 (63 FDIC banks failed between 1960 and 1974; self-serving loans were major cause in $59 \%$ of failures; defalcation, embezzlement, and manipulation in $32 \%$; and managerial weakness in loan portfolio management in $9 \%$ ).

12. I2 C.F.R. $\$ 337.3$ (1977) (new FDIC regulation requiring approval and recordkecping for insider transactions); $i d . \$ \$ 561.28-.37,563.17, .33-.35, .40, .41, .43, .45$ (1977) (new Federal Home Loan Bank Board (FHLBB) regulations for all federally insured S\&Ls, designed to reduce directors' conflicts of interest, including interlocks with other financial institutions).

13. A mutual institution is organized without capital stock and operated for the benefit of its members. In mutual life insurance companies, the members are the policyholders and come within the definition of public creditors. See note 2 supra. In mutual S\&Ls and mutual savings banks, the members are accountholders and borrowers. Accountholders are public creditors, whereas borrowers are not: borrowers do not supply capital and have no claims to assets or profits. Many borrowers, however, are also accountholders.

As of.Sept. 30, 1975, 3480 of the nation's 4092 S\&Ls (including all 2056 federally chartered S\&Ls) were mutual associations. J. FED. HOME LOAN BANK BD., Dec. 1975, at 46. In 1973, about $81 / 4 \%$ of life insurance companies (but representing about $66 \%$ of total life insurance company assets) were mutuals. INstitute of LIFE INSURANCE, LifE INSURANCE FACT Book 89 (1974).

14. Accountholders in mutual S\&Ls are recognized as the legal owners of the business. See L. Conway, Savings and Loan Principles 3, 40 (1958); H. Russeld, Savings and Loan Associations 246 (2d ed. 1960); A. Teck, Mutual Savings Banks and Savings and Loan Assochtions: Aspects of Growth 31 (1968).

The same is true of policyholders in mutual life insurance companies. See Ohio State Life Ins. Co. v. Clark, 274 F.2d 771, 775 (6th Cir.), cert. denied, 363 U.S. 828 (1960); Huber v. Martin, 127 Wis. 412, 105 N.W. 1031, 1036-37 (1906); Hetherington, Fact v. Fiction: Who Owns Mutual Insurance Companies, 1969 Wis. L. REv. 1068, 1070-71; Kreider, Who Owns the Mutuals? Proposals for Reform of Membership Rights in Mutual Insurance and Banking Companies, 41 U. CIN. L. REV. 275, 276, 284-85 (1972).

Like most corporate stockholders, public creditors of mutual S\&:Ls and mutual life insurance companies in practice derive little control over management by virtue of their status as legal owners. See pp. 1433-35 infra; cf. A. Berle \& G. MEANs, The Modern Corporation and Private Property 69-70, 120-21, 277-81 (1940) (discussing "separation" of ownership from control in modern corporations); W. CARY, CoRporations 229-30 (4th ed. 1969) (noting that most stockholders cannot exercise any practical control).

Depositors in mutual savings banks have a status "somewhat in the nature of owners without voting rights." H. Russell, supra at 348 n.18. They do not elect management but do own the assets, profits, and surplus of the bank. See notes 15 \& 16 infra. 
rights of stockholders in stock corporations, including in most cases the right to elect directors ${ }^{15}$ and in all cases a proprietary claim to assets, profits, and surplus. ${ }^{16}$ These rights afford the public creditor of

15. For mutual S\&LL, federal and state regulations usually allow members one vote for each $\$ 100$ of savings (or fraction thereof) to a maximum of 50 votes. Borrowers are usually entitled to one vote regardless of the amount borrowed. See, e.g., 12 C.F.R. $\$ 544.1$ (a) (charter provision 4), (b) (charter provision 4) (1977); Model SAvings AssociaTION ACT $\$ 7(\mathrm{c})$, reprinted in H. RuSSELL, supra note 14 , at 562, 592. In addition to voting privileges, members of mutual S\&Ls can amend the bylaws, approve or disapprove any basic change in corporate policy, request special meetings, nominate and elect eligible directors, run for director if eligible and nominated, and remove directors for cause. See H. RusselL, supra note 14, at 249-60.

At present, voting rights in mutual life insurance companies are generally statutory. See, e.g., New York Ins. Law \$ 198(2) (McKinney 1966); OHIo Rev. Code ANN. \$ 3941.07 (Page 1971). State statutes usually mandate one vote per policyholder, see, e.g., Calif. INs. CoDE $\$ 4016$ (West 1972), although some states allow companies to afford voting privileges commensurate with the amount of insurance held, with the number of policies owned, or on some other equitable basis, provided written permission is granted by the state superintendent of insurance or a similar official. See, e.g., ILL. ANN. Stat. ch. 73, $\$ 654$ (1) (Smith-Hurd 1965); NEw YoRK INs. LAw $\$ 57$ (McKinney 1966).

Public creditors do not elect the managements of mutual savings banks. The trustees or directors (originally, in most cases, the founders) are "either self-perpetuating or selected by self-perpetuating boards of incorporators." A. TEck, supra note 14, at 36. They govern through appointment of salaried officers. L. Conway, supra note 14, at 19; A. TECK, supra note 14, at 36.

16. The annual net earnings of mutual S\&Ls must be either distributed pro rata among the accountholders and depositors (as "dividends" or "interest") or added to legal reserves required by federal regulations. See 12 C.F.R. $\$ \$ 544.1$ (a) (charter provision 10), (b) (charter provision 10), 563.2 (1977) (pro rata distribution of carnings and surplus); id. $\$ \S 563.11$-.13 (required reserves); H. Russell, supra note 14, at 259.60; A. TECk, supra note 14, at 34-35. At present, regulations of the FHLBB, 12 C.F.R. $\$ \$ 526.1$ to $.5-1$ (1977), place a ceiling on the interest payable to depositors. Since S\&Ls usually pay the maximum rate, see notes $25 \& 26$ infra, public creditors' claims to profits and surplus are currently most relevant in liquidation, conversion into a stock company, or merger or consolidation with a stock company. Federal regulations specify accountholders' rights upon conversion. 12 C.F.R. $\$ 563 \mathrm{~b} .3$ (c) (1977) (upon conversion of mutual association into stock association, accountholders must receive without payment nontransferable subscription rights to purchase pro rata number of entitlement shares in new corporation, options on additional shares, and withdrawable accounts in same amount as those in converting association).

Upon dissolution, public creditors of mutual S\&:Ls and mutual savings banks share pro rata in all assets and surplus remaining after satisfaction of debts. In re Cleveland Savings Society, 192 N.E.2d 518, 539-40 (Ohio Ct. C.P. 1960) (mutual savings banks); N.J. STAT. ANN. $\$ 17: 9 \mathrm{~A}-284 \mathrm{~A}$ (West 1950) (mutual savings banks); 12 C.F.R. $\$ 546.4$ (1977) (if S\&L's assets not distributed pro rata, plan of dissolution is subject to FHLBB and accountholder approval); H. Russell, supra note 14, at 259-60 (S\&Ls); A. TECK, supra note 14 , at 13-14, 34-35 (S\&-Ls and mutual savings banks).

The proprietary claims of mutual life insurance policyholders to profits and surplus are more complicated. Here the concepts of "surplus" and "profit" must be distinguished. Mutual life insurance companies are required by statute to maintain certain legal reserves, often called legal "surplus," to guarantee performance of existing policy contracts. This surplus is owned by policyholders. See $18 \mathrm{~J}$. Appleman, Insurance Law and Pracrice ch. 344, § 10059 (1945 \& Supp. 1977). Because mutual life insurance companies are not profitmaking institutions, their earnings in excess of costs (both of providing insurance and maintaining reserves) are termed "divisible surplus" and theoretically must be returned to policyholders in the form of "dividends." Directors, however, have discretion to retain part of these funds as a "contingency reserve." Id. $\S 10061$. See, e.g., 
a mutual institution a direct legal as well as financial interest in preventing depletion of his company's assets. ${ }^{17}$

In financial institutions organized as capital stock corporations, ${ }^{18}$ the stockholders are the legal owners and possess exclusively all proprietary rights. ${ }^{19}$ Public creditors have no rights beyond those embodied in their contracts of deposit or insurance policies. Yet their position otherwise resembles that of their counterparts in mutual institutions: they are as numerous, supply most of their institutions' capital, ${ }^{20}$ and

ILL. ANN. Stat. ch. 73, $\$ 855$ (Smith-Hurd 1965) (permitting but limiting amount of contingency reserves); NEW YoRK INS. LAW $\$ 207$ (McKinney 1966) (placing limits on amount of discretionary accumulation of surplus). Dividends are considered a return of overcharges for insurance protection and are usually applied to reduce future premiums. See $18 \mathrm{~J}$. Appleman, supra ch. $\$ 44, \$ 10060$. Some states require that dividends be distributed annually, e.g., NEw YoRK INs. LAw $\$ 216$ (Mckinney 1966 \& Supp. 1975); some give the directors discretion over when dividends are distributed, e.g., Ill. ANn. Stat. ch. 73, $\$ 666$ (Smith-Hurd 1965). When sound management produces large surplus earnings, see note 23 infra, dividends can provide a significant financial saving for public creditors. In June of 1970, for example, 170,000 policyholders of the New York Life Insurance Company received annual dividends in excess of their annual premiums; 600,000 received dividends in excess of $75 \%$ of their premiums; and 1.44 million received dividends exceeding $50 \%$ of their premiums. H. JosEPHSON, supra note 8 , at 29 n.20.

17. Managements of mutual S\&Ls can redeem a member's account against his wishes. 12 C.F.R. $\$ 544.1$ (a) (charter provision 7), (b) (charter provision 7) (1977). Redemption terminates membership status. The redemption power is justified by management's need for flexibility in adjusting savings-account levels and required reserve ratios, controlling payments of dividends on idle funds, controlling overactive accounts, and realizing tax benefits. See H. RusselL, supra note 14, at 260-61. These bases for the redemption power may imply a good faith obligation to exercise that power only to further legitimate business purposes. See 12A W. Fletcher, Cyclopedia of the Law of Private CorporaTroxs ch. 58, § 5696 (1970 \& Supp. 1976) (nonstock, nonprofit corporations have power to expel members provided there is sufficient cause); id. $\$ 5700$ (expulsion must be in good faith and not for "mere purpose" of promoting private interests).

Managements of mutual life insurance companies may likewise cancel policies and thereby eliminate members. This power of rescission, however, terminates after one or two years. The policy then becomes incontestable and may be canceled only for nonpayment of premiums. J. MACLEAN, Life Insurance 193-97 (1962).

18. All commercial banks are stock institutions. In 1974-75, 612 of 2036 statechartered S\&Ls were capital stock institutions. (All federally chartered S\&Ls are mutuals.) J. Fed. HoMe LoAN BANK Bd., Dec. 1975, at 46. In 1973, about $92 \%$ of life insurance companies were organized on a capital stock basis, although these companies issued less than $1 / 2$ of the face value of existing policies and held only $1 / 3$ of total life insurance company assets. INSTITUTE OF Life INSURANCE, supra note 13, at 26,89 .

19. Stock life insurance companies, however, may allow policyholder election of a minority of the board of directors. J. MAclean, supra note 17, at 348 . Some life insurance companies, moreover, are "mixed" companies, stock companies that issue participating as well as nonparticipating policies. Participating policyholders in such companies share only in earnings remaining after payment of a specified rate of return to stockholders. But such policyholders do have a contractual right to this remainder. See id. at 91-92, 209. To this extent the control of the stockholders over disposition of earnings in mixed companies is diminished. Even in pure stock companies, the funds contributed by policyholders that are allocated to required reserves and surplus, see note 16 supra, must be held for the policyholders' benefit. J. MAcLEAN, supra note 17, at 348-49.

20. The amount of stock capital in commercial banks in 1974 was only $8.5 \%$ of the amount of depósits. In 1975, the same figure for the large banks that report weekly on their condition to the Federal Reserve was $9.3 \%$. Hester, supra note 5 , at 184 , 186 . In all 
have an interest in the proper management of these funds. For although the public creditor of a stock company has no claim to profits and surplus, it is the soundness and efficiency of the institution that determines the safety of his savings as well as the rate of return the institution can pay for the use of his money.

\section{The Types of Harm Suffered}

Insider misconduct inflicts financial harms upon both public creditors and their institutions. In mutual companies insider misconduct may deplete the profits and surplus available for distribution to public creditors. ${ }^{21}$ Such depletion would harm the public creditors of mutual and "mixed" life insurance companies, ${ }^{22}$ which pay dividends that vary with the company's net earnings. ${ }^{23}$ It would not reduce the return

state-chartered S\&-Ls in 1970, permanent capital stock and paid-in surplus totaled \$297 million, while savings capital totaled about $\$ 6.2$ billion. FHLBB, SAvincs AND Home FinANCing Source Book 5 (1970). In 1973, stock life insurance companies had capital stock valued at $\$ 1.9$ billion on their balance sheets. Total premium receipts for all companics (stock and mutual), which represent the amount contributed by the public creditors, totaled $\$ 48.67$ billion. INSTITUTE of LIFE INSURANCE, supra note 13, at 57,66 . Capital invested by stockholders averages about $1.5 \%$ of total assets in stock life insurance companies. H. JoSEPHSON, supra note 8 , at 17.

21. See note 16 supra (detailing the interests of public creditors of mutual institutions in assets, profits, and surplus).

22. See note 19 supra (describing "mixed" life insurance companies).

23. The surplus that a life insurance company may distribute as dividends has four major sources: (1) income on investments in excess of the (usually conservative) assumed rate of return, (2) capital gains, (3) savings from loadings on premiums, and (4) mortality gains. See J. MACLEAN, supra note 17 , at $142-43$. The first two sources clearly may be depleted if management invests company funds with an eye to its own benefit rather than to the company's best interests. The third source, savings from loadings, is a measure of the efficiency of management. The "loading" on a premium is the amount that the company estimates is necessary to cover expenses, unforeseeable contingencies, and (in the case of stock companies) profit. It is added to the net premium (the amount needed for "pure" insurance coverage) to arrive at the gross premium paid by the policyholder. See id. at $\mathbf{9 0 - 9 1}$. Improper expenditures will therefore increase actual expenses and reduce this third source of surplus. The fourth source of surplus, mortality gains, results from longer than expected life spans and is not affected by insider misconduct.

After the amount of available surplus has been ascertained, management is allowed considerable discretion in determining, in accordance with its business judgment, how much surplus should be retained as a contingency reserve and how much should be distributed as dividends. See note 16 supra. The scope of management discretion over the amount and use of surplus creates potential for abuse, for if officers or directors wish to manipulate company funds for their personal benefit, undistributed earnings are readily available. See K. Orren, Corporate Power and Social Change: The Politics of THE LIFE INSURANCE INDUSTRY 74-78 (1974) (discussing management's wide discretion over use of surplus and noting that policyholders have been unsuccessful in attempts to force managements to account for mishandling of surplus).

Dividends paid to policyholders generally do not fluctuate widely. Managements prefer steady, predictable dividends, and most companies adjust the size of the contingency reserve or create a separate "dividend fluctuation fund" in order to maintain the desired flow. See J. MAcLEan, supra note 17, at 145-46. As a result, insider misconduct 
to public creditors of mutual savings and loan institutions (S\&Ls) and mutual savings banks when those institutions pay the maximum interest rates allowed by federal regulations. ${ }^{24}$ These ceilings have frequently proved to be lower than the rate that market forces would dictate, ${ }^{25}$ and therefore an institution that is simply paying the maximum rate often will have sufficient excess earnings to maintain this payout despite insider misconduct. At present, however, interest rates are below the maximum due to declining interest rates in the money market, the result of an expansionary monetary policy by the Federal Reserve System and a limited demand for credit. ${ }^{26}$ Insider misconduct could thus have an immediate effect upon returns to the public creditors of mutual S\&Ls and mutual savings banks. Further-

may have a smaller immediate effect on policyholder dividends than would otherwise be the case. But to the extent that insider misconduct reduces earnings and forces management to pay "normal" dividends from funds like contingency reserves-funds supposedly set aside to protect policyholders in times of trouble-the longer-term interests of the public creditors may be jeopardized.

24. The rates of interest that federally insured S\&Ls may pay are prescribed by the FHLBB, 12 C.F.R. $\$ \$ 526.1$ to .5-1 (1977). Interest rates paid by mutual savings banks are prescribed by Federal Reserve Board regulations if the bank is a member of the Federal Reserve System. See 12 C.F.R. $\$ \$ 208.1-12,217.3(a), .7$ (1977). If a mutual savings bank is not a Federal Reserve System member but its deposits are insured by the FDIC, its interest rates are subject to the limits of 12 C.F.R. $\$ 329.7$ (1977). Most states require FDIC membership for mutual savings banks. A. TECK, supra note 14, at 148.

The current interest rate ceilings for mutual S\&Ls range from $5.25 \%$ to $7.75 \%$, according to the size and type of account. Longer-term accounts of $\$ 100,000$ or more generally have no ceiling. For mutual savings banks, ceilings range from $5 \%$ to $7.5 \%$ for members of the Federal Reserve System, and from $5 \%$ to $7.75 \%$ for FDIC-insured, nonFederal Reserve member banks. In both cases, no ceiling is placed on time deposits of $\$ 100,000$ or more.

25. That the ceilings are often artifically low is suggested by the fact that few institutions ever have been forced to pay rates below the maximum. The average interest rate paid by insured S\&:Ls during the first six months of 1975 , for example, was $6.16 \%$. The prevailing interest ceilings at the time ranged from $5.25 \%$ to $7.75 \%$, with no ceiling on accounts of $\$ 100,000$ or more. J. FED. HoME LOAN BANK BD., Dec. 1975, at 38-39. Almost all commercial banks, mutual savings banks, and S\&:Ls are federally insured and thus subject to interest rate controls. See notes 62 \& 76 infra. There is therefore no incentive for regulators to keep ceilings at or near what would otherwise be the market rate, as they would have to do if regulated institutions were threatened by serious competition from a large, unregulated segment of the industry.

The artificially low rates can produce periods of disintermediation (removal of funds from financial intermediaries) when the Federal Reserve implements restrictive monetary policies, resulting in marketable securities' offering rates of return sufficiently higher than those on deposits to offset the additional costs and risks. See DePamphilis, The Shortterm Commercial Bank Adjustment Process and Federal Reserve Regulation, N.E. EcoN. Rev., May/June 1974, at 14; Mullineaux, Interest-Rate Ceilings and the Treasury-Bill Market: Disintermediation and the Small Saver, N.E. EcoN. REv., July/Aug. 1973, at 19. The early 1970 s was a period of large-scale disintermediation. See Wall St. J., Aug. 27, 1974, at 4, col. 1; id., Aug. 12, 1974, at 13, col. 4; id., Aug. 7, 1974, at 16 col. 3; id., July 29 , 1974, at 13 , col. 1 .

26. Wall St. J., Dec. 22,1976 , at 1 , col. 6. Banks and S\&Ls recently cut their interest rates by as much as a percentage point on some savings accounts in an effort to slow the inflow of savings deposits. Id. 
more, there is no reason to assume that interest rate ceilings are a permanent part of the federal regulatory scheme. ${ }^{27}$ If ceilings were abolished and interest rates were allowed to fluctuate in accordance with market forces and the institution's earnings, insider misconduct could easily decrease the returns paid to public creditors. ${ }^{28}$ In any event, depletion of assets or surplus in mutual companies and "mixed" life insurance companies would reduce their public creditors' pro rata claims to these funds. ${ }^{29}$ Public creditors of stock institutions, although they have no proprietary claims, have the same financial interest as do public creditors of mutual companies in ensuring that managerial misbehavior does not lower the rate of return on their investments. ${ }^{30}$

Moreover, insider misconduct causes direct financial injury to the

27. In 1971, the President's Commission on Financial Structure and Regulation (Hunt Commission) recommended that interest rate ceilings on time and savings deposits be phased out over the next ten years. It also recommended that, after a suitable adjustment period to deter a sudden shift of funds from savings associations to commercial banks, Congress consider removing the prohibition against interest payments on demand deposits. Report of the President's Commission on Financial Structure and Regulation 23-29 (1971) (Hunt Commission Report). These proposals are receiving serious consideration in Congress. See, e.g., Discussion Principles, in FINE STudY PAPERs, supra note 5, at 7-8; Regulation Q: Hearings Before the Subcomm. on Financial Institutions Supervision, Regulation and Insurance of the House Comm. on Banking, Currency and Housing, 94th Cong., 1st Sess. (1975). Cf. R. Robinson \& D. Wrightsman, Findacial M.arkets: The Accumulation and Allocation of Wealth 407 (1974) (noting that "finally the Federal Reserve itself appears to share [the Hunt Commission's] view," and that it now "appears possible that Regulation $\mathbf{Q}$ will be phased out").

28. It might be argued that competitive forces would prevent managements from reducing interest rates below the prevailing market level and that the returns to the public creditors would therefore be unaffected by insider misconduct that reduces earnings. There are two responses to this objection. First, assuming perfect competition, the prevailing interest rate would reflect the maximum that institutions could safely afford to pay. If the management refused for competitive reasons to lower interest rates while stealing from the company, the soundness of the institution itself could be seriously jeoparized. Second, even if competition prevented variations in interest rates, the prevailing rate might be artificially low as a result of pervasive insider misconduct throughout the financial system.

The probable result absent interest rate ceilings, of course, would not be perfect competition at all, especially not nationwide. Other anticompetitive regulatory strategies, such as limitations on entry into the market and geographical restraints on doing business, as well as natural differences among market areas, produce market imperfections and would allow variations in interest rates. See R. Robinson \& D. Wrightsman, supra note 27, at 403-11; Clark, The Soundness of Financial Intermediaries, 86 YALE L.J. 1, 28-44 (1976).

29. See notes 16 \& 19 supra (detailing financial interests of public creditors of mutual institutions and mixed life insurance companies).

30. The rates of interest payable by stock S\&Ls are governed by the same regulations that restrict mutual S\&Ls. See note 24 supra. Interest rates for commercial banks that are members of the Federal Reserve System are regulated by 12 C.F.R. $\$ 217.3(\mathrm{a}), .7$ (1977). The ceilings are the same as those for mutual savings banks within the Federal Reserve System. These ceilings are set out in note 24 supra. All other FDIC-insured commercial banks are subject to the ceilings set by FDIC regulations. 12 C.F.R. $\$ 329.6$ (1977). These ceilings range from $5 \%$ to $7.5 \%$ on time deposits of less than $\$ 100,000$; time deposits larger than that have no ceiling. Savings deposits return a maximum of $5 \%$. 
institution itself, depleting its resources and jeopardizing its soundness. This threatens those public creditors whose savings are not fully covered by back-up funds with the loss of their investments or savings. ${ }^{31}$ In addition, serious difficulties within a single financial institution may disrupt the normal flow of funds in the financial community. ${ }^{32}$ If a financial institution fails because of managerial impropriety, there may also be an adverse impact on public confidence in the financial system, contravening an important congressional and regulatory goal..$^{33}$ This loss of public confidence is exacerbated when, as now, insider misconduct is widespread and causes well-publicized difficulties in prominent financial institutions.

\section{The Inadequacy of Present Remedies}

At present, governmental regulation and existing private rights of the stockholder and public creditor are the only controls over insider misconduct in financial intermediaries. None provides adequate protection for public creditors and their institutions.

\section{Private Remedies}

\section{a. Ordinary Creditors' Remedies}

In all financial institutions considered here, the public creditor is accorded the legal status of creditor. ${ }^{34}$ As such, his most significant right is to demand his money and take it elsewhere. ${ }^{35}$ Although this

31. Back-up funds (federal deposit insurance and state guarantee funds) do not protect all public creditors. See pp. 1445-46 infra.

32. See Davis, Banking Regulation Today: A Banker's View, 31 LAw \& Contemp. Prob. 639,639 (1966) (noting that because bank liabilities "for the most part are held by businesses and individuals and constitute circulating medium," bank failures can paralyze economic life in communities).

33. See Randall, The Federal Deposit Insurance Corporation: Regulatory Functions and Philosophy, 31 LAw \& Contemp. Prob. 696, 696-99 (1966).

34. Davis v. Elmira Savings Bank, 161 U.S. 275, 288, 289 (1896); RestatemENT (SECOND) of Trusts $\$ 12$, comment 1 , at 41 (1959); A. TECK, supra note 14 , at $30-31$ \& nn.6, 7 \& 8 (depositors in mutual savings banks and accountholders in S\&Ls are legal creditors). Although the holder of a life insurance policy is not himself a creditor of the company in the ordinary sense, the company does have a contractual obligation to pay the specified sum to the policyholder's designated beneficiary. In addition, the policyholder is entitled to payment in the form of a surrender value upon discontinuance or cancellation of his policy. See note 35 infra.

35. In practice, all commercial banks, mutual savings banks, and S\&Ls honor withdrawal requests by time and savings depositors on demand, although they may invoke 30-, 60-, or 90-day statutory notice requirements if faced with a liquidity crisis. See $\mathbf{L}$. Conway, supra note 14, at 12-13; A. TECK, supra note 14 , at 30,40 . Withdrawals from time deposit accounts before the agreed date are penalized by law. See note 37 infra.

For life insurance companies, the Standard Nonforfeiture Law, effective in all states since 1948, see J. MACLEAN, supra note 17, at 126, provides for minimum cash-surrender 
"market out" is a valuable option, it does not provide the public creditor with a complete remedy. Information about insider misconduct is not readily available to the public creditor. ${ }^{36}$ Should he fail to discover the institution's problems in time, the public creditor could at best save himself from further financial loss. Moreover, premature withdrawal entails forfeiture of interest on many time deposits. $^{37}$ In mutual companies, withdrawal means giving up interests in assets and surplus. ${ }^{38}$ Switching institutions is inconvenient and may involve loss of longstanding and well-developed credit relationships. ${ }^{39}$ Finally, there may be no acceptable alternatives to a particular institution. ${ }^{40}$

Some public creditors of financial intermediaries, such as corporate depositors, maintain large balances and could attempt to influence management by threatening withdrawal. But the credibility of any such threat would be highly questionable, for withdrawal is a costly and incomplete remedy. Most public creditors have smaller individual

values equal to the present value of the insurance benefit less the present value of adjusted premiums, i.e., the value of the policy reserve less unamortized initial expenses. Most companies pay more than the minimum. The Standard Nonforfeiture Law does not require payment of cash values until premiums have been paid for three years. Nonforfeiture values in the form of paid-up insurance, however, are required as soon as the adjusted-premium formula gives a positive value, usually about two years. The nonforfeiture law provides as well for six-month delay clauses in policies, which allow a life insurance company to postpone cash payments under certain conditions, such as liquidity crises. Like banks and savings associations, however, life insurance companies rarely invoke this privilege. $I d$. at $180-83$.

36. Because the disclosure obligations of financial institutions to their public creditors are minimal and not strictly enforced, see pp. 1434-35, 1440-41 \& notes 49-52, 78, 79, 81 infra, it would be difficult for public creditors to obtain useful information about management activities. If he could obtain such information, the average public creditor would often lack the sophistication to analyze its implications unless it were presented in simple comprehensible form. The costs of obtaining information moreover, need not be large to deter the public creditor, whose stake is usually small. See Clark, supra note 28, at $15-18$.

37. Federal regulations penalize early withdrawals from virtually all time deposits in financial institutions examined in this Note by reducing the interest rate and deducting three months' interest. See 12 C.F.R. $\$ 217.4($ d) (1977) (Federal Reserve System member banks); id. $\$ 329.4$ (d) (FDIC-insured, non-Federal Reserve member banks); id. \$545.1-4(f) (1977) (Federal Home Loan Bank Board member S\&Ls); id. \$\$ 563.3-1(d), .3-2(d) (all S\&Ls insured by Federal Savings and Loan Insurance Corporation).

38. See note 16 supra. This sacrifice would be most acute in mutual life insurance companies, for a policyholder's claim to surplus is determined by how much he has contributed to each source of surplus. See J. MACLEAN, supra note 17, at 146-48; note 23 supra.

39. See R. Robinson \& D. WRIGHTSMAN, supra note 27, at 408 (noting that financial institutions compete not just for particular items of business, but also for good customers, who "are rewarded with more favorable treatment than they can probably expect if they should switch their banking connections").

40. Although unlikely for banks or S\&Ls, this is often the fact in the life insurance business. As a policyholder grows older, especially if his health deteriorates, he may find it difficult or impossible to obtain a new policy on terms comparable with his old one. 
stakes, are numerous and scattered, and present little threat of concerted action.

\section{b. Extraordinary Creditors' Remedies}

Public creditors of financial institutions are granted statutory protection in the event of their institutions' insolvency ${ }^{41}$ and have the right to set aside fraudulent conveyances. ${ }^{42}$ These remedies, however, become available too late to protect ongoing interests in honest management. This is true even of fraudulent conveyance remedies, for creditors cannot call management to account for misapplied funds unless insolvency or its harbingers approach. ${ }^{43}$ These remedies thus do not always provide complete recovery, especially since enforcement costs may be high. Even if they did provide full recovery, however, they would not protect the public creditor of a solvent institution, or, for that matter, the institution itself, from the consequences of insider misconduct.

\section{c. Voting Rights}

Voting rights offer a potential source of protection against managerial abuses, but their utility in controlling the managements of financial institutions is limited. Only in mutual S\&Ls and mutual life insurance companies do public creditors elect their manage-

41. All the financial institutions considered in this Note are subject to federal or state statutes that provide for appointment of conservators, receivers, or liquidators, who take possession of the institution if insolvency is imminent and unavoidable. The major statutory provisions may be found in Clark, supra note 28 , at $89 \mathrm{nn} .260-62$. Such provisions allow regulators to minimize losses by such techniques as arranging for healthy institutions to acquire failed ones, helping to ensure that expert conservators, receivers, and liquidators are appointed, and placing persons who are familiar with the operations and problems of the institution in charge of the reorganization or liquidation. Id. at 99-100.

42. Section 4 of the Uniform Fraudulent Conveyance Act, which has been adopted in 25 states (including California, Delaware, and New York), 7 UNIForm LAws ANN. 423, 470 (West 1970), allow's creditors to set aside conveyances made or obligations incurred by a debtor who is or will thereby be rendered insolvent, if there is no fair consideration given in return for the conveyance or obligation.

Public creditors are "creditors" for purposes of the Uniform Act. See, e.g., Society Milion Athena v. National Bank of Greece, 281 N.Y. 282, 293, 22 N.E.2d 374, 377 (1939). But they have little need to invoke their rights, because, under the special insolvency provisions governing financial institutions, see note 41 supra, conservators or receivers are often appointed before actual insolvency. The receiver or conservator, however, may press claims under the Uniform Act. See Bernheim v. Burden, 253 App. Div. 232, 1 N.Y.S.2d 689 (1938).

43. Section 2 of the Uniform Fraudulent Conveyance Act, 7 UNIForm LAws ANs. 436 (West 1970), terms a debtor insolvent when the present salable value of his assets is less than the amount required to pay his existing debts as they mature. 
ments. ${ }^{44}$ Even there, election procedures provide little practical protection, because there exist few of the statutory provisions-such as proxy regulation-necessary to make the vote meaningful. ${ }^{45}$

Comparison of the protections afforded stockholders with those afforded public creditors underscores this deficiency. Stockholders are protected by state statutes regulating corporate election and decisionmaking processes ${ }^{46}$ and by federal securities law provisions governing proxy solicitation and requiring extensive and accurate disclosures. ${ }^{47}$ These statutes apply only to holders of securities and therefore do not protect public creditors of financial institutions. ${ }^{48}$ The federal and state agencies that regulate mutual S\&Ls and life insurance companies have never promulgated rules of equal rigor. The Federal Home Loan Bank Board (FHLBB), with jurisdiction over all federally insured S\&Ls, has in the past maintained only minimal provisions for disclosure, proxy solicitation, and notice. ${ }^{49}$ Recently, in an effort to regulate conflicts of interest more effectively and to ensure the independence of boards of directors, ${ }^{50}$ the FHLBB mandated more comprehensive disclosure by all insured S\&Ls. This new provision still will not afford public creditors of affected S\&Ls information

44. See note 15 supra.

45. There have been but minimal requirements regarding notice of annual meetings, disclosure of relevant information, and proxy use. See notes 49, 51, 54 infra; Kreider, supra note 14, at 275, 284-90 (describing lack of appropriate legislation and arguing for legislative grant of shareholder rights to public creditors of mutual companies).

46. E.g., Del. Code ANN. tit. \&, \$§ 211-244, $251-262$ (Michie 1975 \& Supp. 1976); N.X. Bus. CoRP. LAw $\$ \S 601-626,801-806$, 901-911 (McKinney 1966 \& Supp. 1977).

47. Securities Act of 1933,15 U.S.C. $\$ \$ 77 \mathrm{a}-77 \mathrm{aa}$ (1970 \& Supp. V 1975) (disclosurc and registration generally); Securities Exchange Act of 1934,15 U.S.C. $\$ 78 \mathrm{n}$ (1970) (proxy regulations).

48. The antifraud provisions of the 1934 Act, however, do protect holders of permanent withdrawable "shares" (accounts) in mutual S\&Ls. Tcherepnin v. Knight, 389 U.S. 332 (1967). The Court based its holding in Tcherepnin on the resemblance that "shares" in mutual S\&Ls bear to investment contracts: their holders "are participants in a common enterprise-a money-lending operation dependent for its success upon the skill and efforts of the management ... in making sound loans." Id. at 338. The Court also relied on the legislative history of the Act. Id. at 340-45.

49. In the recent past, FHLBB regulations required only an annual "statement of condition," 12 C.F.R. $\$ 545.23$ (1977), and required annual meetings, 12 C.F.R. $\$ 544.5$ (charter provisions 1-3) (1977), but did not provide adequate or well-policed notice requirements. For a discussion of the old provisions and their inadequacies, see Herman, supra note 5 , at 789-95.

Proxy regulation by the FHLBB is still minimal. Proxies must be revocable at will and cannot be misleading, 12 C.F.R. $\$ \S 569.2(\mathrm{a}), .4(\mathrm{c})$ (1977), but permanent proxies are permitted, and content is unregulated except for the prohibition of misleading statements. See id. $\$ \S 569.1-.4$.

State law has generally been more permissive than federal, particularly in the areas of disclosure and proxy regulation. See Groebe, Proxy Contests in Savings Associations, Legal Bull., March 1960, at 58-59; Herman, supra note 5, at 790, 795.

50. 41 Fed. Reg. 35814 (1976). 
comparable to that provided stockholders under the securities laws. ${ }^{51}$ Moreover, S\&L managements may deprive a dissident accountholder of "membership" status simply by redeeming his account.52 For life insurance companies, the states often prescribe by statute the number of votes per policyholder, ${ }^{53}$ but generally the election process is governed only by the company's charter and bylaws. ${ }^{54}$ During the initial one or two years that a policy is in force, the company can deprive a policyholder of membership status by canceling his policy. ${ }^{55}$

For these reasons, the voting rights accorded public creditors of mutual S\&Ls and mutual life insurance companies are an ineffective means of policing management. Even if stricter regulations were promulgated and enforced, it is unlikely that voting rights would be effective. The much better-protected corporate stockholder, who exercises at least sporadic control through the election mechanism, often must resort to derivative suits in order to protect his corporation's interests effectively.

\section{d. Protection Through Stockholder Derivative Suits}

Although public creditors of stock financial institutions might derive some vicarious protection from stockholders' exercise of their

51. 12 C.F.R. $\$ 563.45$ (1977). Generally, the new regulation requires insured S\&:Ls to send to all accountholders possessing at least two votes either an annual report or notice of annual meetings with a statement that such reports are available. 12 C.F.R. $\$ 563.45$ (a) (1977). The report must disclose information about officers and directors (including changes in controlling personnel; remuneration and pension, retirement, or other special benefits; and loans and transactions with affiliated persons), voting rights, and the manner of proxy solicitation. $I d . \$ 563.45$. Institutions with assets under $\$ 15$ million are exempt, as are institutions that meet new requirements concerning composition of the board of directors, insider transactions, and manner of voting proxies. Id. $\S 563.45(b)(1)$, (3). This information is inferior to that provided stockholders under the securities laws. Stockholders receive more than the extensive company information found in annual reports and the prospectus. Most important for purposes of intelligent voting, they also receive all material facts about each matter to be voted on at the corporate meeting. Proxy solicitations must disclose this information, as well as the names and interests of participants in proxy contests. Individual votes must be taken on each issuc, and proxy material must be examined and approved in advance by the SEC. See R. JENNiNGs \& H. Marsh, Securities Regulation 30-35 (4th ed. 1977).

52. See note 17 supra; cf. Yancey, Mutual Savings and Loan Associations: Rehabilitation of Membership Rights, 15 SANTA Clara LAw. 635, 643-44 (1975) (noting potential for abuse of S\&L managements' redemption power).

53. See note 15 supra.

54. See Hetherington, supra note 14, at 1075-85; Kreider, supra note 14, at 284-90. Both articles discuss the lack of policyholder influence upon management through the corporate democratic process. See also K. ORREN, supra note 23, at 78 (noting that restrictive requirements for nomination of directors by policyholders and "permanent or 'automatic' " proxies foster "management absolutism"). New York has special provisions dealing with "contested elections" (those in which independent candidates have been nominated). N.Y.-INs. LAW $\$ 198$ (McKinney 1966). If there are no independent nominations, the only requirement is that each policyholder be given one vote, see note 15 supra.

55. See note 17 supra. 
rights, this generally would not be the case. The interests of stockholders and public creditors are not coterminous and can be adverse, even as regards insider misconduct. ${ }^{36}$ The "contemporaneous ownership" rule ${ }^{\tilde{\tau} \tau}$ prevents public creditors from simply buying a share of stock and instituting a derivative suit after misconduct has occurred. Even if a public creditor had the foresight to buy a share of stock at the time he initially bought a policy or made a deposit, a court might view him as attempting to circumvent the contemporaneous ownership rule. ${ }^{38}$ Moreover, such a strategy could never be implemented successfully by all public creditors of stock corporations, for many

56. The stock of financial institutions is often closely held, see note 59 infra; in such cases, the interests of the stockholders are generally the same as those of management. Even in publicly held companies, stockholders offer no reliable protection for public creditors. Stockholders are often apathetic. They may be farther removed geographically from an appropriate forum than many public creditors and hence unwilling to face the inconvenience of bringing suit unless the perceived risks to their investments are quite serious. In addition, the stockholder may well have a smaller proportion of his personal savings invested in the institution; therefore, the risk he is willing to bear is likely to exceed that which the public creditor would voluntarily shoulder. Since nothing guarantees the public creditor an appropriate stockholder representative, the protection derived from this source is at best haphazard.

In addition, there are situations in which stockholders would have no incentive to correct abuses that harm their institutions. A good example is a bank holding company with a wholly-owned banking subsidiary and a non-banking subsidiary. Holding companies (the stockholders of the bank) have often rescued ailing non-bank subsidiaries by having the bank extend financial support to the unsound non-bank institution. See, e.g., FINE STUdY PAPER, supra note 5, at 494-526 (statement of R.A. Schotland). In 1975, the Chase Manhattan Bank had extended over $\$ 150$ million to a related real estate investment trust, including an $\$ 85.5$ million purchase of the trust's non-income-producing loans. The total exposure of the bank via the unsound enterprise amounted to $150 \%$ of the bank's reserve for all loan losses. $I d$. at 497 . The similar, albeit more dramatic, experience of the Beverly Hills Bancorp has been described as "indicating that holding company bank soundness is jeopardized by problems arising outside the banks, either in the parent holding company or in a related unit." Id. at 495 . The same troubles could arise in S\&L or life insurance holding companies. Cf. note 8 supra (failure of life insurance companies due to misconduct of parent holding company management); note 107 infra (documenting regulators' difficulties in controlling life insurance holding company managements). In such situations, the only private parties with an incentive to protect the financial institution are its public creditors. And to the extent that regulation is inadequate to control insider misconduct, see pp. 1437-46 infra, public creditors are the only potential source of control over such abuses.

57. The contemporaneous ownership rule requires that a stockholder have owned shares of the company at the time of the alleged wrongdoing or that he have received the shares thereafter by operation of law. The rule is incorporated into FED. R. Civ. P. 23.1. A major theory behind it is that a stockholder cannot complain of past wrongs if he purchased his shares from one who participated or acquiesced in the misconduct. Bangor Punta Operations v. Bangor \& A.R. R.R., 417 U.S. 703,710 (1974).

58. See, e.g., In re Penn Cent. Transp. Co., 341 F. Supp. 845, 846 (E.D. Pa. 1972) (contemporaneous ownership rule designed to prevent "buying" of lawsuit by persons who purchase stock with intention of bringing derivative action). Even though the public creditor's purpose might be future protection of his interests, as opposed to immediate institution of a lawsuit for past wrongs, his action still might fall within this prohibition. 


\section{Public Creditors of Financial Institutions}

such corporations are closely held. ${ }^{59}$ Shares of these institutions are likely to be expensive or unavailable. ${ }^{60}$ Nor is there any good reason that a public creditor should have to invest in an institution's stock to protect his own limited interests.

\section{The Regulatory System}

Financial institutions are heavily regulated by the federal government and the states. Regulators enforce various policies and rules designed to preserve the soundness of financial intermediaries, but the regulatory strategies of greatest importance to the public creditor are insider misconduct regulation and the use of back-up funds (BUFs). ${ }^{\text {o1 }}$

\section{a. Insider Misconduct Regulation}

Commercial banks and mutual savings banks: Federal regulation of the banking system ${ }^{62}$ is largely a response to various crises and has sought to preserve solvency by regulation of competition and risktaking. ${ }^{63}$ The structure of regulation reflects this orientation, for it is designed mainly to prevent and detect "normal" management errors. ${ }^{64}$ Although there are rules pertaining to insider misconduct, ${ }^{65}$ the

59. Most stock S\&:Ls are closely held. In about half the independent stock S\&Ls in 1968, officers and directors held over $50 \%$ of the stock; in about $1 / 3$ of them, the three largest stockholders held over $1 / 2$ the shares. In stock S\&:Ls controlled by holding companies, the three largest stockholders held over $50 \%$ of the permanent stock in 51 of 61 associations. See Herman, supra note 5, at 904-05. The stock of commercial banks and stock life insurance companies tends to be more widely dispersed.

60. Cf. W. CARY, supra note 14 , at $494-512$ (discussing restrictions on transfer of voting stock in closely held corporations); F. O'NeAL, Close CoRporations $\$ 1.07$ (1958 \& Supp. 1970) (noting lack of market for stock of close corporations); id. $\$ \$ 7.01-.29$ (discussing stock transfer restrictions in close corporations).

61. For a description of the regulatory agencies and the allocation of authority among them, as well as an appraisal of regulation of the soundness of financial intermediaries, see Clark, supra note 28.

62. At the federal level, the Comptroller of the Currency, the Federal Reserve Board, and the FDIC regulate the banking system. Id. at 4-6. Almost all banking institutions are subject to federal regulation, owing to near universal membership in the FDIC. As of Dec. 31, 1974, FDIC-insured banks numbered 14,550 as against 411 noninsured state banks. There were 14,230 insured commercial banks and nondeposit trust companies, 251 noninsured, and 322 insured and 160 noninsured mutual savings banks. 1974 FDIC ANN. REP. 186.

63. See Davis, supra note 32, at 640-41; Randall, supra note 33, at 696 .

64. Scott \& Mayer, supra note 8, at 862 . Scott and Mayer term federal banking supervision a "compulsory management consulting service." Id.

65. See 12 U.S.C. $\$ 375 a$ (1970) (prohibiting loans to executive bank officers); id. $\$ 376$ (favorable interest rates for bank directors, officers, and employees prohibited); id. $\$ 1818$ (penalties and proceedings for unsafe or unsound banking practices or violation of any law, rule, or regulation); 18 U.S.C. $\$ 214$ (1970) (imposing criminal penalties upon bank directors, officers, and employees for receipt of commissions or gifts for procuring loans); 
regulators' lack of access to relevant information historically has impeded enforcement. Regulators have sufficient powers to punish transgressions that come to light ${ }^{66}$ but have conceded that lack of information makes it virtually impossible to detect and prevent management lootings. ${ }^{67}$ New FDIC regulations requiring disclosure and accurate recording of insider transactions ${ }^{68}$ should at least provide regulators with better information, although managements will undoubtedly continue to conceal truly fraudulent conduct. But the new regulations will not alleviate other problems. They will not, for example, affect the overlapping jurisdictions of the three federal banking regulatory agencies, which have significantly impaired effective enforcement of specific rules. ${ }^{69}$

Moreover, there is convincing evidence that federal regulators have deliberately ignored insider abuses in several significant cases. It has been alleged, with considerable support, that the misconduct by the management of Franklin National Bank was known to and reported by federal examiners eight years before that bank collapsed in $1974 .{ }^{70}$

id. $\S 656$ (imposing criminal penalties upon bank officers and employees for theft, embezzlement, or misapplication of funds); 12 C.F.R. $\$ 337.3$ (1977) (requiring disclosure to and approval of insider transactions by disinterested boards of directors).

66. The FDIC has the power to revoke a bank's insurance, 12 U.S.C. $\$ 1818$ (a) (1970); all federal banking agencies can issue cease and desist orders, id. $\$ 1818(\mathrm{~b})$, and remove directors for breach of fiduciary duty, unsafe or unsound banking practices, or violation of laws, regulations, or orders, id. $\$ 1818(\mathrm{e})$.

67. See, e.g., Ailing banks are hard to spot, supra note 11, at 108-09.

68. See note 12 supra.

69. All national banks are subject to regulation and supervision by the Comptroller of the Currency, the Federal Reserve Board (FRB), and the FDIC. State banks that join the Federal Reserve System are automatically insured by the FDIC and thus are subject to the FDIC's jurisdiction as well as to that of the FRB. Non-Federal Reserve member state banks that opt for federal deposit insurance are regulated at the federal level only by the FDIC. See Robertson, Federal Regulation of Banking: A Plea for Unification, 31 Law \& Contemp. Pros. 673, 673-74 (1966). The resulting jurisdictional jumble has created "a situation ... that has never been paralleled ... in terms of complexity, confusion, irrationality, and difficulty of administration." $I d$. at 673 . (The author was then ViceChairman of the Board of Governors of the Federal Reserve System.) Overlapping responsibilities have produced a "patchwork structure of regulation consisting of a battery of contradictory agencies which have often reduced supervision of financial institutions to the lowest common denominator among their conflicting positions." STIFF of Subcomm. on Domestic Finance of the Senate Comm, on Banking and Currency, 93p Cong., 2D Sess., Financial Institutions: Reform and the Public Interest 5 (Comm. Print 1973). Efforts to avoid public conflict have on occasion led to inaction on proposed rules, projecting a false appearance of harmony and resulting in neglect of needed reforms. Bankers have opposed suggested unification of the system on grounds that a single agency would be too powerful or would threaten the dual federal-state banking system. Robertson, supra at 690-91.

70. Ailing banks are hard to spot, BUs. WEEK, Nov. 8, 1976, at 108, 109. Regulators apparently accepted garbled accounts of conditions in the bank. In May of 1974, just before the bank's collapse, the Comptroller of the Currency assured the FRB that Franklin National was solvent and eligible for federal loans, despite the report of his own examiner, disclosed to the bank's president, that the bank was insolvent. ForrunE, Oct. 1974, at 118, 225-26. See also note 8 supra. 
Federal regulators surely knew as early as 1969 about abuses involving the U.S. National Bank of San Diego, which failed in 1973 because of self-serving activities by insiders. Yet no action was taken until 1973 , four years and six official audits later. ${ }^{71}$ A class action by shareholders of U.S. National was filed in 1974 against the Comptroller of the Currency and the Chief National Bank Examiner, alleging negligence in supervision, examination, and, specifically, in failure to discover or correct systematic violations of the National Banking Act. ${ }^{33}$ The Insurance Company of North America has indicated its intention to file a countersuit against the FDIC and the Comptroller of the Currency denying its liability on a fidelity bond covering officials of U.S. National on the ground that regulators concealed instances of fraud and other irregularities at least since 1962.73 These allegations have not been refuted by regulatory authorities. ${ }^{74}$

Such palpable laxity, coupled with the regulatory ineptitude inferrable from the numerous bank failures due to insider misconduct, does little to encourage a prediction that the new regulations, which are prefaced by the assurance that they "do not necessitate changes in the . . . substantive requirements" of existing regulations, ${ }^{75}$ will significantly improve enforcement.

SoLs: The FHLBB is the major agency regulating S\&Ls. ${ }^{76}$ Like its

71. See note 8 supra. The Wall Street Journal ran an article about the misconduct at U.S. National on Apr. 16, 1969, at 1, col. 6. Not until 1973 did the Comptroller of the Currency issue an order to $\mathrm{C}$. Arnholdt Smith, the bank's president, to cease and desist the provision of excessive credit to Westgate-California. Since national banks are audited by federal examiners three times every two years, U.S. National "passed" at least six official examinations between exposure of the abuses and action by the regulators. See Economisr, Oct. 27, 1973, at 109; Wall St. J., Oct. 23, 1973, at 1, col. 4; id., Aug. 6, 1973, at 12 , col. 3 .

72. Wall St. J., May 28, 1974, at 22, col. 3.

73. The fidelity bond stipulated that claims must be filed within six months of the discovery of the wrongdoing. See San Diego Backlash: INA vs. the FDIC, Bus. WeEk, Nov. 8, 1976, at 108-09. One examiner from the San Diego office of the Comptroller of the Currency was transferred to Alaska "shortly after filing a critical report on the bank's condition in 1963." Id. at 109.

74. Indeed, Comptroller of the Currency James E. Smith has admitted in a congressional hearing that federal regulators heard rumors about the abuses at U.S. National as early as 1969 and that the Comptroller's office "may have been deficient" in examining the bank. Senate Hearings, supra note 4 , at 374,382 . He has also refused to release U.S. National's examiners' reports, summaries, or conclusions. Schiebla, Big Bank Failure, Barron's, Apr. 1, 1974, at 3.

75. 41 Fed. Reg. 18405 (1976).

76. See Clark, supra note 28, at 6-7. The FHLBB has jurisdiction over members of the Federal Savings and Loan Insurance Corporation (FSLIC), which insures all federally chartered S\&LL and most state-chartered ones. See J. Fed. Home LoAN Bank Bd., Dec. 1975, at 46 (as of Sept. 30, 1975, ESLIC-insured S\&Ls owned $97 \%$ of resources of operating S\&Ls). State regulation of S\&Ls, "while generally weaker and more subject to industry influence than that of the Federal authorities," has at times played an important role in shaping federal policy on particular issues. Herman, supra note 5, at 923 . Before the FHLBB promulgated its new regulations, see notes 12 \& 51 supra, for example, California had much stricter provisions governing loans to insiders than did the FHLBB. C.AL. Fin. 
banking counterpart, the system of S\&L regulation was designed in large part to cope with competition and risk-taking. Until 1976, the system had failed to define clear-cut standards for dealing with insider misconduct ${ }^{77}$ and to establish adequate disclosure requirements. ${ }^{78}$ Regulatory vitality has been sapped by a consistently "informal and ad hoc" approach to enforcement, which deals with most abuses by the technique of moral suasion. ${ }^{79}$ These defects are especially serious in the S\&L area, for the structure of the industry generates numerous conflicts of interest. so $^{-10}$

The FHLBB has recently issued regulations setting guidelines for the composition of S\&L boards of directors, restricting insider transactions, and requiring certain disclosures. ${ }^{81}$ If these provisions are strictly enforced, the number of objectionable insider transactions in S\&Ls will be reduced. The new regulations, however, do not mention enforcement and do not provide mandatory penalties for violations, which might have worked as a deterrent to future misconduct. If the FHLBB continues to use moral suasion as its major enforcement technique, little improvement can be expected.

One explanation for the ineffectiveness of insider misconduct regulation of banks and S\&Ls may be that the goal of a stable, smoothly functioning financial system conflicts with the goal of aggressive agency enforcement. ${ }^{82}$ Voluntary compliance with the many regulations un-

Cone $\$ \$ 7177-7183$ (West 1968 \& Supp. 1976). But in light of the new federal provisions and the dominance of federally chartered S\&Ls, see Yancey, supra note 52, at 64I n.41 (federal S\&Ls own 70.5\% of all assets for mutual S\&Ls); notes 13 \& 18 supra (1424 of 2036 state-chartered S\&Ls and all federally chartered S\&Ls are mutuals), discussion of various state policies would add little to the present analysis.

77. See T. Marvell, The Federal. Home Loan Bank Board 142 (1969); Herman, supra note 5, at 923-41; Yancey, supra note 52, at 636-37 (noting lack of effective FHLBB supervision and regulations and prevalence of conflicts of interest; also noting existence of abuses, citing Herman, supra note 5, and Wall St. J., Dec. 31, 1971, at 16, col. 1).

78. See note 49 supra.

79. Herman, supra note 5 , at $930,939$.

In 1969, a survey of federal SSL examiners revealed that almost $50 \%$ agreed that regulations and policies regarding conflicts of interest were inadequate. Id. at 931 . Yancey also notes the lack of effective regulatory policy and the often "lackadaisical exercise" of regulatory power. Yancey, supra note 52 , at 651 . He identifics deficiencies in accountholders' rights to control management, procedural obstacles to exercising existing rights, and weaknesses in the structure of information dissemination. Id. at 636. He advocates increasing accountholders' control by allowing them to bring private actions since, given the FHLBB's inability or unwillingness to eliminate abuses through supervision, there exist no real administrative remedies. $I d$. at 652.

80. See note 6 supra.

81. See notes $12 \& 51$ supra.

82. Another explanation might be the effect of political influence on the regulatory scheme. This is harder to document for banking and S\&-L regulation than for life insurance companies, see pp. 1443-44 \& notes 94-96 infra, but members of legislative 
related to insider misconduct ${ }^{83}$ is extremely important in such an extensive system of supervision. Regulators may recognize that the successful enforcement of such regulations requires friendly and cooperative relations with the financial institutions and that these relations might be jeopardized if existing proscriptions of insider misconduct were earnestly enforced. ${ }^{84}$ Thus, there may be a temptation to ignore less serious abuses, especially those that do not clearly threaten an institution's soundness, or to administer only a slap on the wrist in the interest of more effective regulation elsewhere.

Of course, pervasive insider misconduct itself undermines the stability of the financial system. The new FDIC and FHLBB regulations $^{85}$ are a hopeful sign of increased concern about this problem. Yet it is doubtful that they will suddenly transform the regulatory agencies into efficient policemen. And if cooperative relations between regulator and regulated are, in fact, imperative and would be threatened by official action against every transgression, then to increase regulatory efforts could be a costly solution. The need for extraregulatory protection remains.

Life insurance companies: Regulation of the life insurance industry is almost entirely in the hands of the states, although the scope of

bodies often have significant financial interest in banks and S\&Ls. See, e.g., Herman, supra note 5, at $923 \mathrm{nn} .1$ \& 2 . It is likely that political influence has at times caused regulators to overlook abuses. Although the Comptroller of the Currency, when asked why the abuses at the U.S. National Bank of San Diego were so long overlooked, declined to say whether officials of U.S. National complained to the White House about the investigation of that institution, Wall St. J., Nov. 9, 1973, at 17, col. 1, it is well known that its former president, C. Arnholdt Smith, had powerful political connections, in particular to former President Richard Nixon. Wall St. J., Nov. 19, 1973, at 28, col. 1; id., Aug. 6, 1973, at 12, col. 3 .

83. There are extensive regulations designed to control competition, e.g., price restraints (such as limitations on economic return or amount of financial services that institutions may provide to public creditors) and limits on market entry (such as requirements of regulatory approval for new charters, for doing business in new states, for branching and mergers, and for holding company acquisitions). In addition, there is portfolio regulation, in the form of an "cxtensive array of legal rules . . . to restrict the kind, amount, and valuation of [each institution's] assets," an "equally extensive" set of restrictions on the kinds of liabilities and equity claims each institution may issue, as well as "sometimes complex" rules governing initial capitalization and maintenance of certain levels of net worth, capital, or surplus. "Reactive" regulation by BUFs and second-order financial intermediaries is designed to cope with institutional failure and liquidity crises and to administer special insolvency proceedings. See Clark, supra note 28, at 29-32, 44-47, 86-89.

84. See, e.g., Herman, supra note 5, at 926 \& n.15 (noting importance of good will for purposes of regulatory efficiency and consequent circumscription of regulatory action, particularly in S\&L regulation).

85. See notes 12 \& 51 supra. 
federal authority remains unsettled. ${ }^{86}$ The existing regulatory pattern originated as a response to widespread abuses by insiders, ${ }^{87}$ and many states continue to restrict various kinds of insider transactions. ${ }^{88}$ The major emphasis of the system, however, has been on ensuring solvency, ${ }^{80}$ primarily through reserve requirements and investment restraints. ${ }^{90}$ Such an approach does not encourage regulators to focus directly upon insider misconduct. Moreover, the focus on solvency has sometimes directed scarce regulatory resources to examination of smaller or weaker companies, leaving the larger, "sounder" ones rela-

86. The McCarran-Ferguson Act, 15 U.S.C. $\$ \S 1011-1015$ (1970), was enacted in 1945 in response to the Supreme Court's holding in United States v. South-Eastern Underwriters Ass'n, 322 U.S. 533 (1944), that the business of life insurance constitutes interstate commerce if conducted across state lines. The Act provides that the business of life insurance is subject to federal regulation only to the extent that it is not regulated by the states. The scope of federal control has not yet been delineated, particularly in the antitrust area. See, e.g., SEC v. National Securities, 393 U.S. 453 (1969); Addrisi v. Equitable Life Assurance Soc'y of United States, 503 F.2d 725 (9th Cir. 1974), cert. denied, 420 U.S. 929 (1975); Fry v. John Hancock Mutual Life Ins. Co., 355 F. Supp. 1151 (N.D. Tex. 1973).

87. The basis of the present state regulatory patterns was established in the ycars following the 1905 Armstrong Investigation of life insurance companies in New York, See 10 Report of the Legislative Insurance Investigating Committee, N.Y. Assembly Doc. No. 41 (1906). The Armstrong Investigation exposed a multiplicity of insider abuses and prompted a virtual overhaul of insurance regulation in most states. See generally $\mathrm{M}$. Keller, The Life Insurance Enterprise, 1885-1910 (1963). Most of these early reforms were aimed at restricting permissible investments, eliminating interlocks with bank and trust companies, prescribing certain minimum standards for policyholder democracy in mutual and "mixed" companies, and eliminating the "deferred-dividend" system. See J. MACLEAN, supra note 17 , at 591-95.

88. E.g., Ill. ANN. STAT. ch. 73, $§$ 736.1-.2 (Smith-Hurd 1965 \& Supp. 1977); N.Y. INs. LAw $\$ 78$ (McKinney 1966 \& Supp. 1976). The Illinois law allows some insider transactions if approved by the board of directors.

That insider misconduct continues to cause insolvencies in the life insurance industry indicates that existing regulations are either inadequate or unenforced. See p. 1424 \& note 8 supra.

89. See H. Denenberg, et AL., Risk AND Insurance 462-68 (1964) ("central and most important purpose [of insurance regulation] has been described as that of maintaining the solvency of the insurer"); K. ORREN, supra note 23, at 67 (noting "nonexistence of standards and goals" for life insurance regulation, beyond safety (solvency) and preservation of state revenue). The numerous sources on life insurance regulation after the Armstrong era mention insider misconduct regulation only indirectly or, more often, do not mention it at all. J. MACLEAN, supra note 17, for example, does not discuss regulation of insider misconduct at all in its chapter on governmental regulation, id. at 503-16, and mentions it only in connection with a historical "review" of the origins of the Armstrong Investigation. Id. at 591-96. See also Insurance, Government, and Social Policy: Studies in Insurance Regulation (S. Kimball \& H. Denenberg eds. 1969) [hereinafter cited as Insurance Regulation]. Evidently there has been little state regulatory activity in this area, but not because the present regulations are effective. See p. I424 \& note 8 supra.

90. See J. MAclean, supra note 17 , at $504,511,513$. The states also regulate the terms of the policy contract, the organization and licensing of new companies, and the licensing of agents. Id. at 504, 513. 
tively unsupervised.91 Historically, the system has failed to prevent insolvencies. ${ }^{92}$

The failure of life insurance regulators to control insider misconduct probably stems from structural defects in the regulatory systems, rather than from lack of substantive rules. ${ }^{93}$ There has developed a high level of accommodation and cooperation between legislators, regulators, and the industry. ${ }^{94}$ The system as a whole is highly polit-

91. K. ORREN, supra note 23 , at 44 . The Illinois insurance department's examiner in charge of office auditing has stated:

We aren't concerned with the big companies . . . . We're concerned about companies that would go under. ... If we got a complaint, even then I don't think we could realistically go into it. But we're really not interested anyway. Even if there was a potential conflict, it would be alright if it wasn't hurting the company, even though the officer might benefit. Looking at it realistically, [the big companies] would probably never go out of business.

Quoted in id. at 45. But see National Ass'n of Ins. Comm'rs, supra note 10, at 1-7 (regulating system generally wastes manpower by spending undue time examining large companies unlikely to have solvency problems).

92. Epton \& Bixby, Insurance Guaranty Funds: A Reassessment, 25 DePaul L. Rev. 227, 229 (1976); K. ORREN, supra note 23, at 45-46. According to statistics of the National Association of Insurance Commissioners (NAIC), regulators have considerable difficulty even detecting insolvency. During the past decade, 52\% of insolvent companies were detected by "complaints and information from outside sources," $40 \%$ by regulatory examination, and only $8 \%$ by financial analysis. National Ass'n of Ins. Comm'rs, supra note 10, at 3-1. Insider misconduct has been the primary cause of most life insurance company insolvencies. $I d$.

93. The NAIC has recommended a "restructuring" of the system of insurance regulation to deal with perceived difficulties in detecting problem companies, in gathering sufficient information (specifically in the areas of internal company controls and holding company relationships), and in using manpower effectively. National Ass'n of Ins. Comm'rs, supra note 10 , at $2-1$ to $2-3,1-5$ to $1-8$.

The discussion following in the text relies heavily upon $K$. OrRen, supra note 23. Although that study was based on in-depth analysis of the politics of life insurance regulation in Illinois, it was "not intended as a state study, sealed off from the broader picture .... Insurance politics in Illinois are representative rather, in that the same network of forcign and domestic companies, their lobbyists and associations, as well as the circumstances arising from the ambiguities of power in a federal system, are common to the others." Id. at 16.

94. Id. at 27-28. In Illinois, the insurance department depends on the companies for a varicty of services. The department uses accountants provided by the companies to conduct its examinations and audits and the companies' lobbyists to advance regulatorindustry interests in the legislature. Id. at 42-43. Spencer Kimball, speaking of state insurance regulation in general, has noted that

on the whole the "corruption" has been very subtle and unconscious but nonetheless quite pervasive and real. The insurance regulator ... too often . . conceives himself, as a part of the industry, existing to serve the industry. Indeed, I have heard life insurance men express the notion that it would be useful to have a national regulator to "represent" the industry ... Nothing unsavory was intended. . . However, the notion that a regulator should "represent" the industry is a subtly corrupted point of view.

Kimball, The Case for State Regulation for Life Insurance, in InsuRANCE REgulation, supra note 89 , at 411,432 . 
ical, and the companies exercise great influence..$^{95}$ Legislators frequently have private interests in the insurance industry. ${ }^{96}$ Malfeasance and conflicts of interest are recurrent problems in insurance departments. ${ }^{97}$ In addition, most insurance departments are vested with "primary jurisdiction" over insurance company activities; this restricts the access of private parties to judicial remedies.98

Because life insurance companies are sources of substantial tax revenues and regulatory fees, ${ }^{99}$ insurance departments desire to retain jurisdiction over companies doing business in their states. This renders regulators vulnerable to the demands of the industry, which can threaten to throw its political influence behind movements for federal regulation. ${ }^{100}$ The National Association of Insurance Commissioners (NAIC), which has a reputation for disinterested expertise in insurance regulation, operates under an "implicit understanding that any NAIC policies or recommendations which are too distasteful might provoke the companies into taking the federal option."101 In addition, state insurance departments compete with each other to attract companies; the multiplicity of jurisdictions creates "a field played by the life insurance industry with great skill and to consistent advantage" in obtaining favorable regulatory treatment. ${ }^{102}$

Finally, shortages of funds and manporver in insurance departments

95. K. ORREN, supra note 23, at 40-69. The companies' political power has been traced to campaign contributions, material services to legislators (such as loans and mortgages), and the technical expertise these companies can offer. This results in industry-dominated insurance committees in the legislature and legislative reliance upon the views of the insurance department and the industry. $I d$. at 61-65.

96. In the Illinois legislature from 1961 to $1968,20-24 \%$ of the Senators and $16-19 \%$ of the House members were engaged in the insurance business in private life. The corresponding figures for members of legislative insurance committees are $31-58 \%$ in the Senate, $20-33 \%$ in the House. $I d$. at 49,51 .

97. Id. at 46 n.13. Compare Kimball's observations, quoted in note 94 supra. He notes, in addition, insurance regulatory agencies' "susceptibility to sundry political pressures of a less subtle" and "not always the most savory" kind. Insurance Regulation, supra note 89 , at 432 .

98. See Kavanaugh v. Underwriters Life Ins. Co., 231 S.W.2d 753, 755-56 (Tex. Civ. App. 1950) (adopting primary jurisdiction as Texas's rule; citing decisions of Kansas, Maine, New York, and Ohio state courts and secondary authorities); cf. Guardian Life Ins. Co. v. Bohlinger, 308 N.Y. 174, 183, 124 N.E.2d 110, 114 (1954) (absent specific statutory provision, decisions of Superintendent of Insurance not subject to judicial review; court notes that "provisions to protect policyholders against unwise, improvident or illegal expenditures . . . generally do not provide for judicial re-examination").

99. Life insurance companies are extremely important to state finances. They provide many jobs, pay taxes and fees for licenses and other privileges, and make large investments and bank deposits. K. ORREN, supra note 23, at 16 .

100. Id. at 35. Tax revenues and regulatory fees would be jeoparized by federal regulation, as would the positions of insurance department personnel. $1 d$. at $35 \& \mathrm{nn} .32 \& 33$.

101. Id. at $35-36$.

102. Id. at $36,37-39$. 
reduce the effectiveness of regulation. ${ }^{103}$ This problem is exacerbated by the growing number of new companies, especially life insurance holding companies. ${ }^{104}$ Holding companies are particularly problematic because they are immune from state insurance regulation ${ }^{105}$ and boast a history of insider abuse of their state-regulated subsidiaries. ${ }^{106}$ Regulators have acknowledged extensive problems with holding companies and have expressed pessimism about their ability to control holding company managements. ${ }^{107}$

\section{b. Back-up Funds}

BUFs are the major regulatory means of protecting public creditors from the realized risks of institutional failure..$^{108}$ Deposits in almost all commercial and mutual savings banks are insured up to $\$ 40,000$ by the FDIC. ${ }^{109}$ Accounts in most S\&Ls are insured to the same extent by the Federal Savings and Loan Insurance Corporation (FSLIC). ${ }^{110}$ Sixteen states and Puerto Rico have created BUFs for life insurance companies. ${ }^{111}$ BUFs thus provide protection for many, but not all, public creditors.

BUFs rescue public creditors only after an institution has become insolvent. In this respect they resemble extraordinary creditors' remedies $^{112}$ and like them cannot combat the effects of insider misconduct on a solvent institution. Yet failure is not an inevitable nor even the most common effect of insider misconduct. And public creditors, even

103. H. Josephon, The Case Against New Life Insuraice Companies 69-72 (1966); K. ORREN, supra note 23 , at $42-43$.

104. H. JosepHSON, supra note 8 , at 145-74; K. ORREN, supra note 23 , at 1-3, 82-83.

105. State regulation generally extends to insurance holding companies only insofar as the holding company's activities affect a subsidiary insurer subject to state regulation. See, e.g., Mich. Comp. LAws ANN. \$\$ 500.1301-.1379 (West Supp. 1977) (subjecting mergers and acquisitions of domestic insurers to registration and approval requirements; providing for registration of domestic insurers that belong to holding company systems; and regulating terms of material transactions between domestic insurers and their affiliates); NEW YoRK INS. LAw $\$$ 69-d (McKinney Supp. 1976-77).

106. H. JosephSON, supra note 8, at 44-46, 51-54; K. ORREN, supra note 23, at 85 .

107. In response to a questionnaire from the New York Insurance Department, about $1 / 2$ of the 35 responding state regulatory agencies reported problems arising from holding companies, including intercorporate transactions between insurance and noninsurance subsidiaries. State of New York Ins. Dep't, Report of the Special Comm. on Ins. Holding Companies 50.53 (1968), cited in K. ORREN, supra note 23, at 85.

108. See Clark, supra note 28 , at 86 .

109. 12 U.S.C. $\$ \$ 1813(\mathrm{~m}), 1817(\mathrm{i}), 1821(\mathrm{a})(\mathrm{l})$ (Supp. V 1975). See note 62 supra.

110. 12 U.S.C. $\$ 1724$ (b) (Supp. V 1975). See note 76 supra.

111. For the statutory citations, see Epton \& Bixby, supra note 92, at $250 \mathrm{n} .120$. New York is one of these states. See N.Y. INs. LAw $\$ 224$ (McKinney 1966 \& Supp. 1976-77) (establishing Life Insurance Guarantee Corporation). In addition, most state insurance departments arrange reinsurance agreements when a company becomes insolvent, thereby minimizing policyholder losses.

112. See p. 1433 supra. 
in stock companies, have cognizable interests in ensuring honest management in ongoing institutions. ${ }^{113}$

BUFs were not intended to insulate self-dealing managements from liability. The insurer as regulator may prosecute wrongdoers; when regulation, as now, is ineffective, the public creditor, as the party in interest before failure, should have a right to correct abuses in ongoing institutions. It would be illogical to assert that a BUF eliminates this interest in honest management or that the BUF should deprive the public creditor of a right to vindicate his interest.

\section{The Appropriateness of a Derivative Suit}

Supplementing currently inadequate creditors' remedies with a new private right of action is preferable to relying solely upon reform of the regulatory system. Regulation has proved ineffective in controlling insider misconduct, and adequate reform of the system would be difficult because of the problems of discretionary non-enforcement and lack of resources.114 A private remedy would be prey to neither of these problems and, moreover, would not jeopardize the cooperative relations that may be essential to other regulatory goals. ${ }^{115}$

In analogous contexts in which regulation has proved inadequate, courts have found private rights of action implicit in the regulatory scheme. The Securities and Exchange Commission (SEC), for example, relies heavily upon supplementary private enforcement to offset its shortages in time and manpower, ${ }^{116}$ and the Supreme Court recognizes private enforcement as a "necessary supplement to [SEC] action."117 On occasion, Congress has explicitly provided that "aggrieved" private

113. See pp. 1425-31 supra.

114. See Dam, Class Actions: Efficiency, Compensation, Deterrence, and Conflict of Interest, 4 J. LEGAL STUD. 47, 67 (1975) (noting that enforcement by public agencies is impeded by lack of resources). Such problems are common in public regulatory agencies. See, e.g., Homburger, Private Suits in the Public Interest in the United States of America, 23 Buffalo L. REv. 343, 376 (1974) (noting that administrative agencies are reluctant to attack politically powerful offenders and do not command adequate resources for enforcement); Landes \& Posner, The Private Enforcement of Law, $4 \mathrm{~J}$. LEGAL STud. 1, 36-38 (1975) (noting that budgets of public enforcers are small in relation to potential gains from enforcement as appraised by private, profit-maximizing enforcers and that discretionary non-enforcement by public agencies is common); 74 ColvM. $\mathrm{L}$. REv. 528, 539-40 (1974) (advocating allowing any member of public to bring private derivative action in right of railroad companies, as supplement to enforcement by overburdened or lethargic ICC enforcers who fail to protect public interest).

115. See pp. 1440-41 supra.

116. See J.I. Case Co. v. Borak, 377 U.S. 426, 432 (1964) (possibility of civil liability in private actions a most effective weapon in enforcement; SEC does not have resources for adequate enforcement of Investment Company Act).

117. Id. 
parties may enforce regulatory policies by seeking judicial review of agency inaction in several areas of governmental regulation..$^{118}$

The private right should be derivative because it would enable the institution to recover. Insider misconduct that harms the institution by depleting its assets clearly gives rise to an institutional cause of action. Individual actions for personal recoveries would be inappropriate, primarily because of the difficulties of tracing individual harms back to specific instances of misconduct. The interests of the public creditor in sound management and his stake in the economic viability of his institution justify allowing him to represent the institution. Several compelling precedents for extending derivative rights of action to public creditors demonstrate not only that public creditors would take advantage of such a right, but also that Congress and state legislatures have deemed private derivative actions an appropriate means of augmenting governmental regulation.

\section{A. Precedents}

\section{Mutual Life Insurance Companies}

Illinois accords policyholders in mutual life insurance companies the right to bring derivative actions. The Illinois Supreme Court has held that the state insurance code does not give the Commissioner of Insurance exclusive power to sue and that policyholders need not make a "useless" demand that he take action before suing on their own. ${ }^{119}$

118. See, e.g., Administrative Procedure Act $\S 10$, 5 U.S.C. $\$ 702$ (1970); Federal Communications Act of $1934 \$ 402(\mathrm{~b})(6)$, 47 U.S.C. $\$ 402(\mathrm{~b})(6)$ (1970); Federal Power Act $\S 313,16$ U.S.C. $\$ 825 l$ (1970).

It should be noted that in special circumstances the courts have bcen willing to review public agency non-enforcement of regulatory statutes. At first blush, this would seem to afford public creditors a roundabout means of enforcing proper standards of managerial responsibility. But the cases indicate that such access to the courts would be available to public creditors only in extreme cases of nonfeasance. See Adams v. Richardson, 356 F. Supp. 92 (D.D.C. 1973), aff'd in relevant part, 480 F.2d 1159 (D.C. Cir. 1974) (en banc) (private plaintiffs have standing to seek review of HEW's lax enforcement of Title VI of Civil Rights Act of 1964, 42 U.S.C. $\$ 2000$ d (1970 \& Supp. V 1975); plaintiffs demonstrated virtual abandonment of enforcement effort, and court stressed Supreme Court's decisions mandating immediate dismantlement of dual school systems); American Pub. Health Ass'n v. Veneman, 349 F. Supp. 1311 (D.D.C. 1972) (plaintiffs allowed to seek judicial review of FDA non-enforcement of new drug efficacy requirements despite FDA claim that enforcement was discretionary; court relied on unequivocal language of statute, which ordered FDA enforcement).

119. Winger v. Chicago City Bank \& Trust Co., 394 Ill. 94, 67 N.E.2d 265 (1946) (policyholder suit to compel director to restore misapplied funds). The terminology used by the Illinois courts is confusing; the right of action is sometimes referred to as "derivative," sometimes as a "class action." But in the cases cited below, the cause of action was essentially to vindicate the corporation's interests. See People ex rel. Benefit Ass'n of Ry. Employees v. Miner, 387 Ill. 393, 56 N.E.2d 353 (1944) (policyholder action 
Nebraska courts have reached the same conclusions. ${ }^{120}$ The Supreme Court of Michigan has implied that policyholders may sue derivatively. ${ }^{121}$ In New York, the question has never been decided by the Court of Appeals, but language in several cases suggests that a policyholder's right to sue derivatively might be recognized. In declining to pass on the question, the New York courts analogized policyholder derivative suits to stockholder derivative suits for purposes of determining whether certain prerequisites (such as exhaustion of other available remedies and demonstration of directors' bad faith) had been fulfilled. The courts concluded that because the prerequisites had not been satisfied, it was unnecessary to decide whether a policyholder's right to sue derivatively would be upheld. ${ }^{122}$ California

to remove existing directors, force new election, and require old directors to restore to company money wrongfully spent); Dale v. Hancock County Mut. Life Ass'n, 361 IIl. 222, 2 N.E.2d 96 (1936) (policyholder suit to enjoin execution of irregularly adopted bylaws and tcrms of corporate constitution).

120. See Pathfinder Life Ins. Co. v. Livingston, 140 Neb. 354, 299 N.W. 537 (1941) (policyholder "suit in equity" seeking judgment in favor of corporation against directors who had misappropriated funds); Whaley v. Matthews, 134 Neb. 875, 280 N.W. 159 (1938) ("suit in equity" alleging wrongful diversion of company funds); Folts v. Globe Life Ins. Co., 117 Neb. 723, 223 N.W. 797 (1929) (class action).

121. Glover v. Diggs, 368 Mich. 430, I18 N.W.2d 278 (I962) (policyholder class action alleging misappropriation of company funds). The court stated that "[i]f a suit of this nature ... may be regarded as analogous to an action by a stockholder of a corporation when duly authorized by law, like rules of procedure must be obserred." 368 Mich. at 434,118 N.W.2d at 280-81. Relief was denied because the policyholder had not made the corporation a party to the action.

122. See Clifford v. Metropolitan Life Ins. Co., 264 App. Div. 168, 34 N.Y.S.2d 693 (1942) (derivative action by policyholders of mutual life insurance company sceking injunction and money damages in favor of insurance company). The court stated that there was

some doubt as to the correctness of the contention of the directors that it must be held, as a broad and arbitrary rule of law, that a policyholder has no standing to bring a derivative action in behalf of his insurance company. . . The policyholder of a mutual life insurance company ... has a property interest in surplus and a voice in the management.

264 App. Div. at 171, 34 N.Y.S.2d at 695-96. The court did not decide that a policyholder could bring a derivative suit, however, because the plaintiff-policyholder had failed (1) to exhaust available remedies by making a demand on Superintendent of Insurance and (2) to show that the directors' failure to take the desired action had constituted a breach of duty to the corporation. The court accordingly dismissed the complaint. The issue was avoided again in Garfield v. Equitable Life Assurance Soc'y of United States, 24 App. Div. 2d 74, 263 N.Y.S.2d 922 (1965), aff'd, 17 N.Y.2d \$41, 218 N.E.2d 322, 271 N.Y.S.2d 281 (1966) (in action to recover attorneys' fees for earlier unsuccessful derivative action, plaintiff-policyholder had failed to prove, as required in stockholder derivative suits, that some new asset or fund for company had been created or that company had derived any substantial benefit from previous action). Cf. Imberman v. Alexander, 203 Misc. 576, 116 N.Y.S.2d 609 (Sup. Ct. 1950), aff'd, 281 App. Div. 656, 117 N.Y.S.2d 682 (1952), aff'd mem., 305 N.Y. 820, 113 N.E.2d 560 (1953) (state's requirement of security for expenses in stockholder derivative actions not applicable to policyholder's derivative suit because life insurance policies are not "securities" under statute; court did not decide whether action was class action or derivative suit, although plaintiff had asked that directors be required to return to company profits realized as result of misconduct). 
provides that as to "the management, records, and affairs of a mutual insurer," members have "the same character of rights and relationships as a stockholder has toward a domestic stock insurer ..."; this apparently would sanction a policyholder derivative suit. ${ }^{123}$ Federal law evidently allows a policyholder to bring a derivative action if the state of incorporation of the insurance company in question grants him such a right. ${ }^{124}$

This case law, though sparse, indicates not only that courts have recognized the substantive interests of the public creditor, but also that public creditors would use a derivative right of action to combat insider abuses. The policyholders who instituted the actions noted above appear to have been average public creditors with relatively small individual stakes. ${ }^{125}$ They were concerned with remedying misconduct in solvent companies; in only one case had the institution been rendered insolvent by the alleged misconduct. ${ }^{126}$

\section{Mutual Funds}

The mutual fund ${ }^{127}$ shareholder is a public creditor. ${ }^{128}$ Indeed, his position exemplifies the hybrid creditor-owner status of public creditors of financial intermediaries. Unlike the stockholder in an ordinary business corporation, the mutual fund shareholder has the creditor's option of forcing the corporation to pay him the net asset value of

123. Calif. Ins. Code $\$ 4015$ (WVest 1972). This section was adopted in 1963. It has yet to be construed by the courts.

124. See Koster v. Lumbermens Mut. Cas. Co., 153 F.2d 888, 890 (2d Cir. 1946), aff'd, 330 U.S. 518 (1947) (dictum) (policyholder of automobile liability insurance company incorporated in Illinois had standing to sue because "[i]n reason [there was] no valid distinction between a stockholder's and a policyholder's derivative suit seeking relief" on behalf of company for waste of corporate assets).

This case was decided long before adoption in 1966 of FED. R. Civ. P. 23.1, which allows "shareholders or members" to sue derivatively. The language of Rule 23.1, read in conjunction with the Koster opinion, strongly implies that a policyholder would still be considered a "member" for purposes of bringing a derivative suit if the law of the state of incorporation grants him this status.

125. Whaley v. Matthews, 134 Neb. 875, 280 N.W. 159 (1938) (holders of "thrift certificates" requiring premiums of $\$ 1$ per month for ten years); Clifford v. Metropolitan Life Ins. Co., 264 App. Div. 168, 34 N.Y.S.2d 693 (1942) (individual policyholders alleging diminution in value and earnings of their policies and dividends).

126. Pathfinder Life Ins. Co. v. Livingston, 140 Neb. 354,299 N.T. 537 (1941).

127. "Mutual fund" is a synonym for "open-end investment company," i.e., an investment company that "is offering for sale or has outstanding any redeemable security of which it is the issuer." Investment Company Act of $1940, \S 5(a)(1), 15$ U.S.C. $\$ 80 a-5(a)(1)$ (1970). Almost all mutual funds are "diversified," i.e., at least $75 \%$ of their total assets are represented by cash or cash items or securities "limited in respect of any one issuer to an amount not greater in value than 5 per centum of the value of the total assets ... and to not more than 10 per centum of the outstanding voting securities of such issuer." Id. $\$ 80 \mathrm{a}-5(\mathrm{~b})(1)$.

128. See note 2 supra. 
his shares. Unlike the "ordinary" creditor, he has no individual bargaining power over the terms of his contract. Like other public creditors, mutual fund shareholders usually have relatively small individual stakes in the enterprise but collectively supply all its capital; they own pro rata all assets and profits (reflected by the net asset value of their shares), and supposedly have a voice in management through the voting process. Moses $v$. Burgin ${ }^{129}$ established the right of a mutual fund shareholder to protect his interests through a derivative suit. The First Circuit held that the Investment Company Act of $1940^{130}$ was intended to protect mutual fund shareholders from selfdealing by management and that this purpose could best be accomplished if private parties as well as the SEC could bring suit. ${ }^{131}$ Mutual fund shareholders have frequently taken advantage of their derivative right of action. ${ }^{132}$

The reasons for concern about the position of the mutual fund shareholder emphasize the similarity of his position to that of other public creditors. In a 1966 report to Congress, ${ }^{133}$ the SEC noted that mutual fund shareholders are not merely individual clients of an investment advisor and that their interests in the fund demand the protection of the fiduciary principles of corporate law. ${ }^{134}$ The SEC cited the mutual fund shareholder's inability to bargain over the terms of an advisory contract or the level of sales load and stated that in the absence of such effective bargaining power, "fundamental questions of public policy are raised."135 Finally, the SEG maintained, the "contention that redeemability obviates the need for other share-

129. 445 F.2d 369 (1st Cir.), cert. denied, 404 U.S. 994 (1971).

130. 15 U.S.C. $\$ \S 80 a-1$ to $80 a-52$ (1970 \& Supp. V 1975).

131. 445 F.2d at 373 , interpreting 15 U.S.C. $\$ \S 80 \mathrm{a}-1$ (b), 80a-35, 80a-43 (1970 \& Supp. V 1975). Cf. p. 1446 \& note 116 stepra (noting Supreme Court's implication of private rights of action to assist SEC enforcement).

132. See Fogel v. Chestnutt, 533 F.2d 731, 734 \& n.1 (1975) (noting "large number of derivative stockholders['] actions brought on behalf of mutual funds;" citing Butowsky, Fiduciary Standards of Conduct Revisited-Moses v. Burgin and Rosenfeld v. Black, 17 N.Y.L.F. 735, 736 (1971), and Comment, Mutual Funds and Independent Directors: Can Moses Lead to Better Business Judgment?, 1972 Duke L.J. 429, 430 n.8).

133. SEC Report on the Public Policy Implications of Investment Company Growth, H.R. REP. No. 2337, 89th Cong., 2d Sess. 76-77 (1966) [hereinafter cited as SEC REPORT].

134. The SEC stated that "[t]here is no adequate substitute for these principles," id. at 76, and emphasized the similarities between mutual fund shareholders and holders of corporate securities: "[o]ne who invests in shares of other publicly held corporations relies on the expertise and diligence of their managers in much the same way as the mutual fund shareholder relies on the expertise and diligence of the funds' managers." Id. at 76. The Commission concluded that it was "essential" that basic principles of corporate law be applied to the funds. $I d$.

135. Id. 
holder protections is ... questionable."136 The Commission noted that stockholders in other publicly held corporations can sell their shares on an exchange or in the over-the-counter market, but that the free alienability of the shares has never been viewed as lessening the responsibility of corporate management to the shareholders. ${ }^{137}$

The SEC's observations are equally applicable to public creditors of other financial intermediaries. Neither mutual fund shareholders nor other public creditors can bargain effectively over contract terms; neither group can withdraw from an injured institution without loss. Both groups supply most of the capital to their institutions, which perform the same basic intermediating functions. ${ }^{138}$ Neither group has been able to control insider misconduct by using disclosure requirements and internal corporate control processes. ${ }^{139}$ Derivative actions are appropriate in both cases.

\section{Private Pension Plans}

Private pension plans are first order financial intermediaries; ${ }^{140}$ their public creditors are the beneficiaries (employees) who in effect contribute portions of their salaries to be pooled and invested. The plans are managed by "fiduciaries," usually banks or insurance companies. Beneficiaries of these plans share characteristics common to public creditors of banks, life insurance companies, S\&Ls, and mutual funds. ${ }^{141}$

136. Id.

137. The "free alienability" of mutual fund shares is analogous to the "market out" option enjoyed by other public creditors. See pp. 1431-33 supra.

138. There are few salient differences between mutual funds and the other financiai institutions considered here. One is that there are no BUFs for mutual funds; hence mutual fund shareholders stand to suffer greater losses as a result of insider misconduct. A second difference is that mutual funds invest virtually all their assets in riskier securities; other financial institutions are limited by law to safer securities. The effects of insider misconduct in mutual funds are also more immediate, for returns are not regulated by interest rate ceilings. That the funds of other public creditors are exposed to less risk and that the effects of insider misconduct are more slowly realized and less visible, however, cannot discount the existence of such effects and should not be reasons for denying public creditors the legal right to object to dishonesty in management.

139. The legislative history of the Investment Company Act of 1940, supra note 130, shows that regulation under the securities acts had failed to eliminate abuses by mutual fund managements and that investors were unable to protect themselves. See, e.g., S. REp. No. 1775, 76th Cong., 3d Sess. 6-8 (1940); H.R. Rep. No. 2639, 76th Cong., 3d Sess. 9-10 (1940); $c f$. SEC REPORT, supra note 133, at 72 (noting that as of 1968, conflicts of interest were serious problem in mutual fund industry). That mutual fund shareholders use their derivative right of action, see note 132 supra, indicates that they are often unable to correct perceived abuses through other procedures.

140. See note I supra.

141. Like all public creditors, beneficiaries make small individual contributions which constitute a large part of the capital to which they have a claim. Although employers make contributions to the pension plans, such funds are essentially a part of the em- 
The Employee Retirement Income Security Act of 1974 (ERISA) ${ }^{142}$ was Congress's response to the failure of previous legislation and regulation to control malfeasance and improper activities by pension administrators, trustees, and other fiduciaries. ${ }^{143}$ The Act makes fiduciaries personally liable to make good any losses and restore to the plan any personal profits resulting from breach of their fiduciary duties. ${ }^{144}$ And even though ERISA provides for comprehensive public regulation of private pension plans, Congress did not restrict access to the courts to the Secretary of Labor, under whose regulatory jurisdiction private pension plans fall. ${ }^{145}$ ERISA grants plan participants or beneficiaries the right to sue derivatively to enforce the liability provisions of the Act. ${ }^{146}$ This supports the contention that a supplementary private right of action in the form of a derivative suit is an appropriate means of providing additional protection for public creditors of other financial intermediaries, even though these public creditors do not exercise all the ownership rights of stockholders in ordinary business corporations.

ployees' compensation, which they probably would receive in some other form (e.g., higher wages) if the employers did not contribute to the plan. Further, pension plan beneficiaries have no individual bargaining power over plan terms. They have a financial interest in ensuring that managerial impropriety docs not deplete plan assets or lower its earnings. Like public creditors of commercial and mutual savings banks, see pp. 1426-27 $\&$ note 15 supra, private pension plan beneficiaries do not elect the "managements" of the plans.

The Seventh Circuit recently held that beneficiaries' interests in their pension plans are "securities" for purposes of the antifraud provisions of the federal securities laws. Daniel v. International Brotherhood of Teamsters, No. 76-1855 (7th Cir., Aug. 20, 1977). The court stressed that interests in pension plans are investments in a common enterprise and analogized them to shares in mutual funds. See, id., slip op. at 14-25.

142. 29 U.S.C. $\$ \S 1001-1381$ (Supp. V 1975).

143. H.R. ReP. No. 93-533, 93d Cong., 2d Sess. 3, reprinted in [1974] U.S. Code Cong. \& AD. NEwS $4639,4641$.

144. 29 U.S.C. $\$ 1109$ (Supp. V 1975). Exculpatory provisions are void, although insurance is permitted. Id. $\$ 1110$.

145. The Secretary of Labor may enforce all the provisions of ERISA, with a limited exception for plans which meet the requirements of I.R.C. $\$ \S 401$ (a), 403(a), 405(a). 29 U.S.C. $\$ 1132(a)(5)$, (b) (Supp. V 1975).

146. 29 U.S.C. $\S 1132(a)(2)$ (Supp. V 1975) allows a beneficiary to enforce the provisions of $i d$. $\$ 1109$. See note 144 supra. A beneficiary may also sue in his own right under 29 U.S.C. $\$ 1132(a)(1)(B)$ (Supp. $V 1975)$ to receive benefits, under id. $\$ 1132(a)(1)(A)$ to obtain information, and under $i d$. $\$ 1132(\mathrm{a})(3)$ for injunctive relief.

There is no indication that Congress expected labor unions, rather than individual beneficiaries, to take advantage of the private derivative right. Individual beneficiaries have already invoked ERISA's provisions. See, e.g., Martin v. Bankers Trust Co., 417 F. Supp. 923 (W.D. Va. 1976) (beneficiary seeking benefits allegedly due); PEvsron \& Profit-Sharing ReP. (P-H) I 135,I64 (1976) (describing Harris v. Stryco Mfg. Co. (N.D. Cal. 1976), a beneficiary's suit alleging violations of ERISA's prohibitions, seeking injunctive relief and damages to compensate for losses to pension plan); id. If 8.1 (Jan. 30, 1976) (describing Verderber v. Paramount Moving \& Storage (E.D.N.Y. 1976), in which beneficiary sued officials who had failed to honor his request for documents; plaintiff sought documents and ERISA's $\$ 100$ per day penalty for failure to comply with request). 


\section{B. The Benefits of Supplementary Private Derivative Enforcement}

The proposed derivative right will produce no benefit unless public creditors bring suit. Although the economic stake of public creditors is usually small, it does not follow that they would not exercise their right of action. ${ }^{147}$ The cases discussed above demonstrate that public creditors have utilized derivative suits in a variety of contexts. Some individuals whose financial stakes are small in absolute terms depend upon the returns on their investments and therefore would be quick to protect their small stakes, unless derivative suits were prohibitively expensive. Moreover, unsophisticated plaintiffs, with little or no economic stake in the outcomes of their lawsuits, frequently bring stockholder derivative suits and class actions. They have done so to enforce regulations to protect their small financial interests ${ }^{148}$ or to vindicate their private, non-monetary interests. ${ }^{149}$

147. Yancey, supra note 52, has also noted that public creditors of mutual S\&Ls would have incentives to challenge dishonest management through private actions. $\mathrm{He}$ stresses that creditors have direct and indirect financial interests, see pp. 1425-31 \& notes $14,16,19,23,28$ supra; that not all are covered by federal savings and loan insurance, $c f$. pp. 1445-46 supra (arguing that BUFs not only do not destroy public creditors' financial interests but also are irrelevant to question of "standing" to sue); and that services and conveniences of particular institutions would be a motivation as well, see p. 1432 and note 39 supra. Yancey, supra note 52 , at 662.

148. A good example is Surowitz v. Hilton Hotels Corp., 383 U.S. 363 (1966). The plaintiff was a Polish immigrant with limited knowledge of English and no formal cducation. She had worked as a seamstress in New York City and had saved several thousand dollars, investing $\$ 2000$ in Hilton Hotel stock. Her sole economic concern was that Hilton had cut its dividends. See 383 U.S. at 368-70.

In Eisen v. Carlisle \& Jacquelin, 417 U.S. 156 (1974), a purchaser of odd-lot securities brought a multi-million-dollar antitrust class action against securities dealers who had inflated odd-lot differentials. His economic stake in the outcome was $\$ 70$. Id. at 160-61.

149. Many class actions have been instituted by groups with no economic stake whatsoever. See, e.g., United States v. Students Challenging Regulatory Agency Procedure (SCRAP), 412 U.S. 669 (1973); Sierra Club v. Morton, 405 U.S. 727 (1972); Scenic Hudson Preservation Conf. v. Federal Power Comm'n, 354 F.2d 608 (2d Cir. 1965), cert. denied, 384 U.S. 941 (1966). Taxpayers have challenged governmental and congressional activities that did not threaten them with direct economic injury. See, e.g., United States v. Richardson, 418 U.S. 166 (1974); Schlesinger v. Reservists Comm. to Stop the War, 418 U.S. 208 (1974); Flast v. Cohen, 392 U.S. 83 (1968).

It could be argued that a public creditor who institutes a derivative suit would thereby jeopardize any special credit relationship he might enjoy. See p. $1432 \&$ note 39 supra. This might occur if the entire management of the institution is guilty of misconduct. If only one or several officers or directors were defendants, however, the probability of retributive action would be reduced to the extent that supervision by the board is a check upon misconduct by management. Indeed, there might well be a tendency to placate potential plaintiffs to avoid having misconduct brought to the attention of a responsible board of directors or to the attention of the public. Moreover, even if individuals occasionally lost such advantageous relationships, the large-scale deterrent effect of the proposed derivative right would protect many public creditors from insider misconduct. See p. 1454 infra. 
The great benefit from these suits would be significant deterrence of insider misconduct. The derivative suit has "played a rather important role in protecting shareholders of corporations from the designing schemes and wiles of insiders who are willing to betray their company's interests in order to enrich themselves."150 Few suits need be brought to convince managements of financial institutions that self-dealing is not worth the risk of personal liability, administrative sanctions, and damage to personal reputation. That management cannot predict or control the timing of such suits or the identity of potential plaintiffs enhances this deterrent effect. ${ }^{151}$

The inevitable objection to this private attorney general approach is its potential for abuse by plaintiffs' attorneys. The problem is real but is not a persuasive reason for rejecting the powerful weapon of derivative enforcement. Undoubtedly the plaintiffs' bar would be the motivating force behind many derivative suits brought by public creditors. But there are adequate sanctions to deal with lawyers who bring strike suits or otherwise engage in unethical activity. ${ }^{152}$ If attorneys remain within the bounds of professional ethics, they should be allowed to encourage meritorious lawsuits that serve the public interest by deterring insider misconduct. ${ }^{153}$ Moreover, the

150. Surowitz v. Hilton Hotel Corp., 383 U.S. 363, 371 (1966).

151. ERISA's liability provisions have already produced signs of increased deterrence of insider misconduct by private pension plan fiduciaries. See, e.g., Braverman, Fiduciary Liability under the Pension Reform Law of 1974, Pension \& Profit-Sharing Rer. (P-H) If 1025 (1976) (noting that fiduciaries must protect themselves "against even the remotc possibility of litigation"); Kudish, Investment Management and Fiduciary Responsibility under ERISA, 1 DIREcTORS \& BOARDS 6 (1976) (setting out "practical approach" to meeting ERISA's standards and advising avoidance of conflicts of interest).

For additional documentation of the deterrent value of private actions, see Dam, supra note 114, at 49, 55-61; Landes \& Posner, supra note 114, at 9-10 (documenting positive correlation between private enforcement and probabilities of apprehension, conviction, and penalty). Cf. Yancey, supra note 52, at 663 (arguing that increasing control of mutual S\&-L accountholders over management would deter management abuses).

152. The American Bar Association's Code of Professional Responsibility forbids a lawyer to recommend employment for himself or his partners or associates to non-lawyers who have not sought his advice on employing an attorney, or to compensate persons for recommending him. ABA Code of Professional Responsibility EC 2-4, DR 2-103. It does not prohibit him from giving unsolicited advice to laymen that they should seck legal counsel or take legal action, but provides that he shall not accept employment resulting from that advice. Id. at DR 2-104(A). An explicit exception to that rule is that "[a] lawyer may accept employment from his participation in activities designed to educate laymen to recognize legal problems, to make intelligent selection of counsel, or to utilize available legal services if such activities are conducted or sponsored by a qualified legal assistance organization." Id. at DR 2-104(A)(2).

Thus a lawyer would be guilty of unethical practice in this respect only if he directly solicited plaintiffs for his personal practice. Encouraging individuals or groups to exercise their legal rights, however, is not a violation of the Code. This leaves ample room for an active and helpful private attorney general role for the plaintiff' bar.

153. It has been argued that entrepreneurship on the part of plaintiffs' attorneys is no longer troubling per se and that courts, in declining to permit actions that benefit 
central role of the attorney means that a great number of non-meritorious suits would be screened out. Assuming adequate judicial supervision of settlements, the attorney's fee generally would depend on his prosecuting a successful action; he would naturally be unwilling to press a spurious claim. ${ }^{154}$

\section{Implementation of the Derivative Right}

The most effective method of implementing a derivative right for public creditors would be federal legislation similar to ERISA. ${ }^{155}$ This legislation should set out the nature of the interests to be protected, define the scope of management duties and liabilities, and detail the procedures for enforcement.

\section{A. Recognition and Limitation of Substantive Interests}

The act should state explicitly that public creditors have substantive interests beyond mere fulfillment of their investment contracts. To guard against public creditors' using the derivative suit to harass

only lawyers, have overlooked the public interest served by greater deterrence. An "attractive by-product [of increased private enforcement] would be that the effects of the public enforcement agencies would be supplemented to the fullest degree by the talents and energies of the private bar." Dam, supra note 114 , at 60-61, 69-70. Greater deterrence would increase public confidence in the stability and integrity of the financial system. Yancey, supra note 52, at 663. See also Capelletti, Vindicating the Public Interest through the Courts: A Comparativist's Contribution, 25 Bufralo L. REv. 643, 647-48, 660-63 (1976) (noting that large-scale social wrongs can be remedied only by new large-scale procedures such as private attorneys general and private actions combined with governmental control or initiative).

154. In addition, procedural mechanisms such as the motion to dismiss operate to screen out frivolous claims in the early stages of the suit.

Effective administration of suits actually filed would not be difficult. Indeed, administration would be simple compared with the problems posed by many class actions. Notice requirements would be less troublesome, for the public creditor would sue in the right of his institution. Nor would "standing" pose problems. The public creditor clearly suffers cognizable indirect injury; moreover, the legislation proposed in Part III to implement the derivative right would place the public creditor's interest within the "zone of interests" protected by the statute. Warth v. Seldin, 422 U.S. 490, 500 (1974) (statute involved must "properly [be able to be] understood as granting persons in the plaintiff's position a right to judicial relief").

Although judicial supervision of settlements would create some administrative burden, the courts have developed devices for facilitating efficient judicial supervision, including appointment of special masters, monitors, and committees. The courts have recognized that the judiciary has sufficient safeguards to handle class and derivative actions. "[A] 'full arsenal of adaptable methods is available to assure the fair and efficient conduct of the action.'" Kauffman v. Dreyfus Fund, Inc., 434 F.2d 727, 737 (3d Cir.), cert. denied, 401 U.S. 974 (1971). Derivative suits should provide significant deterrent value without imposing undue administrative burdens upon the courts.

155. An amendment to the McCarran-Ferguson Act, 15 U.S.C. $\$ \S 1011-1015$ (1970), would be necessary to make clear that insider misconduct is not part of the "business of insurance" which the Act entrusts to state regulation. 
management or interfere with the proper exercise of business judgment, the legislation should emphasize that public creditors' legal interests under its provisions are limited to controlling insider misconduct that injures the institution in question; they should not extend to questioning management activities untainted by fraud or conflicts of interest.

\section{B. Scope of Duties and Liabilities}

The act should establish that officers and directors of financial intermediaries owe a fiduciary duty to their public creditors not to deal with their institutions for their own accounts or derive personal profit from transactions in which their institutions engage. Certain insider transactions should be prohibited outright. This category should include transactions that create a presumption of favoritism or self-dealing so strong as to outweigh considerations of management discretion. An example would be loans to insiders on terms substantially more favorable than those governing comparable loans to outsiders. A second category might designate certain transactions permissible if approved by the board of directors after full disclosure of all insider interests. ${ }^{156}$ Examples would be loans to insiders and business transactions with companies affiliated with insiders when either involve more than a specified amount. ${ }^{157}$ Loans to and transactions with insiders which are executed in the ordinary course of business on

156. ERISA limits insider transactions in a manner similar to that recommended in the text. Transactions with interested parties and with fiduciaries are prohibited, and fiduciaries are not allowed to receive compensation for negotiating any transactions. 29 U.S.C. $\$ 1106$ (Supp. V 1975). A plan's acquisition and holding of the employer's securities and real property is limited by id. $\$ 1107(a)$, (b). The Secretary of Labor may grant exceptions to the prohibitions if he finds such action to be administratively feasible, in the interests of the plan and its beneficiaries, and protective of participants' and beneficiaries' rights. Id. \$1108(a). Certain transactions (such as loans to insider-beneficiaries that are made on the same terms governing loans to other beneficiaries and are equally available to all beneficiaries, and transactions for services with insiders if no more than reasonable compensation is paid) are exempted by $i d . \$ 1108(b)$ from the prohibitions of id. $\$ 1106$. Cf. 12 C.F.R. $\$ 337.3$ (1977) (FDIC regulation requiring disclosure to and approval by boards of directors for certain insider transactions). Regulators could tailor this requirement to require approval of outside or disinterested directors for certain transactions. Board approval, of course, would not be an absolute test of fairness and would not preclude a challenge to the transaction's propriety. General guidelines for board approval should be set out in the act or specifically delegated to regulatory authorities for formulation, in order to give boards and courts criteria with which to judge the acceptability of the transaction.

157. Cf. 12 C.F.R. $\$ 563.43(\mathrm{~b})(\mathrm{l})$ (1977) (FDIC restriction on insider loans permitting exceptions for some loans less than $\$ 10,000$ ); $i d$. $\$ 337.3(\mathrm{~b})$ (FHLBB regulation requiring board of director approval for insider transactions of more than a certain aggregate amount). 
standard terms and do not involve more than a specified aggregate amount could be permitted without specific approval by the board.

Officers and directors would be personally liable to make good any losses to the institution and to return any personal profits resulting from any violation of their fiduciary duties under the act. Fines or punitive damages could be imposed in egregious cases. In addition, liability established under the act could be made the basis for automatic regulatory sanctions. As in ERISA, exculpatory provisions should be void, although insurance could be permitted. ${ }^{158}$

\section{Record-keeping and Disclosure}

Institutions should be required to keep full and accurate records of all insider transactions. ${ }^{159}$ This information should be available to public creditors as well as to regulators.

158. ERISA prohibits exculpatory provisions but specifically allows fiduciaries or the plan to purchase liability insurance to cover fiduciaries' actions. 29 U.S.C. $\$ 1110$ (Supp. V 1975).

Most director and officer liability insurance policies contain clauses excepting from coverage any liability established on the basis of fraud or personal dishonesty or in violation of public policy. For this reason, such policies function more to police than to exculpate. See Clark, Liability Insurance for Savings Association Divectors, Officers, and Inside Counsel, LEGAL BuLl., Mar. 1977, at 57, 65 (liability based on violation of conflictof-interest regulations would not be covered by directors' and officers' insurance because most policies exclude losses resulting from successful claim that insured unlawfully gained "'any personal profit or advantage" "). But cf. Bishop, Sitting Ducks and Decoy Ducks: New Trends in the Indemnification of Corporate Directors and Officers, 77 YAlE L.J. 1078, 1088-90 (1968) (ambiguities in some policies could lead to coverage of some liabilities resulting from self-dealing, e.g., excessive compensation). With respect to litigation under the proposed statute, insurance would probably reimburse individual officers and directors for the expense of defending unsuccessful suits if the corporation did not indemnify that individual. It might also reimburse defendants who settle cases if certain standards are met, e.g., cases in which the defendant establishes that he acted honestly and in the best interests of the institution. See Bishop, supra at 1079.

159. The FDIC's new regulations for all insured commercial and mutual savings banks might provide a model for transactions requiring board approval:

[Records] shall include all documents and other material relied upon by the board in approving each transaction, including the name of the insider, the insider's position or relationship that causes such person to be considered an insider, the date on which the transaction was approved by the board, the type of insider transaction and the relevant terms of the transaction, any other pertinent facts which serve to explain or support the basis for the board's decision, and any statements submitted for the minutes or the file by directors or trustees who voted not to approve the transaction setting forth their reasons for such vote.

12 C.F.R. $\$ 337.3$ (d) (1977). Such records must be "in a manner and form that will enable examiner personnel to identify such insider transactions." Id. The regulatory agencies in charge of particular classes of institutions could require that this information be supplemented if necessary or set forth in a particular format. In the S\&L area, for example, these disclosures could be incorporated into the annual report required by the new FHLBB regulations; the report already includes other pertinent information such as changes in controlling persons. See note 51 supra. 
A minimal level of disclosure directly to public creditors is also necessary. ${ }^{160}$ Public creditors currently are not entitled to receive information about insider transactions. ${ }^{161}$ Without this information, it would be difficult for them to make effective use of their derivative right of action, for they usually would be unaware of actual or potential abuses. At a minimum, a brief summary of all insider transactions requiring approval of the board of directors should be provided to all public creditors with a statement that more complete information is available. ${ }^{162}$

\section{Civil Enforcement and Procedural Limitations}

Public creditors should be given the right to sue in federal court to enforce the provisions of the act. ${ }^{163}$ Attorneys' fees should be re-

160. ERISA requires direct disclosure to participants and beneficiaries of a summary plan description, "written in a manner calculated to be understood by the average plan participant," which must include identification of the plan; the name and address of the person designated to receive service of legal process, of the administrator of the plan, and of each plan trustee; descriptions of relevant provisions of collective bargaining agreements; the plan's requirements and its source of financing; and the name of any organization through which plan benefits are provided. 29 U.S.C. $\$$ 1022(a)(1), (b) (Supp. $V$ 1975). In addition, plan administrators must send certain information from their Internal Revenue registration statements to all participants. Id. $\$ 1025(\mathrm{c})$. Participants and beneficiaries may bring civil actions to enforce these disclosure requirements. Id. $\$ 1132(a)(3)(B)$, (a)(4). If an administrator fails to furnish participants or beneficiaries with required information, they may demand that he do so; if he fails to respond by sending the appropriate documents within 30 days, he may be held personally liable to the participant or beneficiary for as much as $\$ 100$ per day from the date of his failure or refusal to comply. Id. $\$ 1132(\mathrm{c})$. One beneficiary has already brought suit under this provision. Prentice-Hall Pension \& Profit-Sharing Rep. đ 8.1 (Jan. 30, 1976) (describing Verderber v. Paramount Moving \& Storage (E.D.N.X. 1976)).

161. S\&:L accountholders covered by the new FHLBB regulations are now entitled to certain information about insiders. See note 51 supra.

162. The required disclosure document might state that the complete records may be inspected at the main office of the institution. If this office is inaccessible, more information could be sent to the interested person upon receipt of proper postage and specification of the desired information. Enforcement procedures and penalties for noncompliance should be set forth in the statute. ERISA's provisions, see note 160 supra, are a useful model.

The costs of compliance with the recommended disclosure requirements would not be high. The record-keeping requirement in particular would not be unduly expensive. The FDIC has already decided that such records are necessary for regulatory purposes, see notes $12 \& 159$ supra. The direct disclosures to public creditors are more problematic but still feasible. The required information need only be briefly summarized, for these direct communications would not serve the purpose of full and detailed disclosure. The complete information would be available to the interested public creditor at his own expense. Since financial institutions correspond regularly with their public creditors anyway, sending them periodic bank statements or notices that policy premiums are due, the costs of additional enclosures should not be prohibitive. Cf. Yancey, supra note 52, at 661 (arguing that costs of increasing mutual S\&:L accountholders' control would be minimal).

163. The act should specifically provide that managements of S\&Ls and life insurance companies may not exercise their powers of redemption after a public creditor has 
coverable. Because of the danger of strike suits, however, certain procedural limitations are necessary.

Public creditors should be required to make a demand on the board of directors, unless the futility of meeting this requirement is demonstrated to the satisfaction of the court. Such a demand, backed by the threat of litigation, could be a powerful incentive to correct abuses. This incentive would be enhanced by requiring a demand on the appropriate regulatory authority if management failed to take remedial action to the complainant's satisfaction. In addition, a demand on the regulators would stimulate regulatory action while leaving the enforcement initiative to the public creditor. This arrangement should help preserve the necessary cooperative relations between regulators and the institution. Because most public creditors are of modest means, security for expenses should not be required. ${ }^{164}$ Settlements should not be allowed without court approval.

\section{E. Integration into the Present Regulatory Structure}

The proposed legislation would supplement rather than preempt existing regulation. The managerial duties it sets forth would not radically change existing substantive rules. New standards would be imposed only in states that currently have no statutory prohibitions of insider misconduct in life insurance companies. The provisions for exceptions to the prohibition of insider dealings could be drawn in a manner that would leave regulators sufficient latitude to tailor the act's requirements to the specific needs of the institutions they supervise. ${ }^{105}$ The proposed disclosure requirements would not be disruptive, for regulators already examine institutional records for

instituted an action, or in an attempt to prevent him from instituting an action. See note 17 supra.

164. Security for expenses poses tremendous problems for a bona fide litigant of modest means. The negative value of deterring meritorious suits in this arca would often outweigh the positive value of deterring strike suits. Adding a requirement of security for expenses would be a simple matter if the strike suit problem proves uncontrollable within the recommended framework. Measuring the negative value of deterring meritorious suits if security were required, however, would be next to impossible. There should therefore be no initial requirement of security for expenses. It should be noted that not all states require security for expenses in stockholder derivative suits; the most prominent example of one that does not is Delaware. See Cary, Federalism and Corporale Law: Refleclions Upon Delaware, 83 Y YLE L.J. 663, 686 (1974).

165. For example, the act could allow regulators to specify the aggregate amount of loans to or transactions with insiders that would trigger the requirement of board approval and to define more specifically such terms as "ordinary course of business." See pp. $1456-57$ \& notes $156-157 \& 159$ supra. 
irregularities. The most onerous new task would be supervising direct disclosures to public creditors. The limited amount of direct disclosure would mitigate this burden. Private actions might spur increased regulatory activity, and therefore cause greater administrative expense, to the extent that regulators choose to intervene or appear as amici curiae: Yet the act would give regulators the options of preempting the private action by correcting abuses through existing regulatory channels or of leaving the matter entirely to private enforcement. The regulatory systems as a whole would function much as they do now, for the recommended private right would extend only to cases of misconduct, never to other subjects of regulation. 